\title{
Physicochemical Properties and Determination of Some Bioactive Phytochemical Constituents From Linum Usitatissimum L Oil (Flaxseed) by Gas Chromatography-mass Spectrometry (GC-MS) and Atomic Absorption
}

\author{
Rasha Khalid Abbas ${ }^{1,2}$ \\ ${ }^{1}$ Department of Biochemistry, Faculty of Applied and Industrial Science University of Bahri, \\ Sudan \\ ${ }^{2}$ Department of Chemistry, Faculty of Science and Arts in Mukhwa, University of Albaha, 65931 \\ Saudi Arabia
}

DOI - http://doi.org/10.37502/IJSMR.2021.4501

\begin{abstract}
Flaxseed (Linum usitatissimum L.) is an important source of oil, The dried seed of flaxseed 100 $\mathrm{g}$, produced $38 \%$ of oil extracted by n-hexane, the physiochemical properties of flaxseed such as acid value $(0.71 \mathrm{mg} \mathrm{KOH} / \mathrm{g})$ as oleic acid, peroxide value $(2.69 \mathrm{meq} \mathrm{O} / \mathrm{kg})$, saponification value $(186.50 \mathrm{mg} \mathrm{KOH} / \mathrm{g}$ oil $)$, and iodine value $(96.67 \mathrm{~g} / 100 \mathrm{~g})$, density $(0.91 \mathrm{~g} / \mathrm{cm} 3)$, refractive index (1.39 and at $28^{\circ} \mathrm{C}$ ), viscosity (CST) (68.33). Gas Chromatography-Mass Spectrometry (GC-MS) was used to identify bioactive phytochemical constituents it contained 26 compounds identified, the major compound were 9-Octadecenoic acid (Z)-, methyl ester (Oleic acid) (43.72) act as antioxidants, anti-cancer, Hexadecanoic acid, methyl ester (Palmitic acid) (17.36) act as Anti-oxidant, decrease blood cholesterol, anti-inflammatory, 9,12,15-Octadecatrienoic acid, methyl ester, $(Z, Z, Z)$ fatty acids: $\alpha$-Linolenic acid, an omega-3 (n-3) fatty acid $\gamma$-Linolenic acid, an omega-6 (n-6) fatty acid (15.72), Octadecanoic acid Methyl stearate (13.13) used As a food additive, soaps, cosmetics, detergents lubricants, softening and release agents, 13-Docosenoic acid, methyl ester, (Z)-(1.31), cis-11-Eicosenoic acid, methyl ester (0.96) act as Antibacterial, antitumor, antifungal, cytotoxic. Atomic absorption is used to identify minerals content it contains Calcium 1180ppm, Copper 4.1ppm, Ferric 15.7ppm, Zinc 34.58ppm.
\end{abstract}

Keywords: Flaxseed (Linum usitatissimum L); physicochemical properties. Gas Chromatography-Mass Spectrometry (GC-MS): Atomic absorption.

\section{Introduction}

Linum usitatissimum L. the common name flax or linseed belongs to the family Linaceae is an annual herb ${ }^{[1]}$. It is beneficial in the chemical composition used as food oil (36 to $40 \%$ of oil) plant rich in essential fatty acids (e.g., a-linolenic acid) that reduce the risk of coronary heart diseases ${ }^{[2]}$ and the prevention of breast and prostate cancers ${ }^{[3]}$. Flaxseed oil is the richest plant source of oleic, linoleic (omega-6) and linolenic (omega-3) polyunsaturated fatty acids (PUFA), which are essential for humans. It contains a lot of bioactive phenolic compounds, which have biological activity including antimicrobial, antiradical, antioxidant and anticancer effects ${ }^{[4,5,6,7]}$. Flaxseed Linum usitatissimum L contains the lignan, secoisolariciresinoldiglucoside (SDG) these 


\section{2 | International Journal of Scientific and Management Research 4(5) 1-29}

lignan have biological activities as antioxidant and antibacterial ${ }^{[8]}$. Flaxseed is an important source of fiber $(20 \%)$ and protein, (30\%) ${ }^{[9]}$. they include mainly phenols, polyphenols, tocopherols, anthocyanins and carotenoids ${ }^{[10]}$. These compounds mainly antioxidants are synthetic or natural compounds that can delay some types of cell damage and quench reactive radical species formed during oxidative reactions in metabolism ${ }^{[11,12]}$.

\section{Material and Methods}

\section{Material}

Flaxseed (Linum usitatissimum L.) Purchase in the supermarket and identified in the Department of Biology, College of Science, Khartoum University.

\section{Method}

\section{Extraction of flaxseed Oil}

$200 \mathrm{~g}$ of prepared seed samples were packed in extraction thimble and inserted into the Sox let extractor, the solvents used n-hexane temperature $\left(40-60^{\circ} \mathrm{C}\right),(500 \mathrm{~mL})$ were separately refluxed for $8 \mathrm{~h}$. At the end of the period, each of the solvents was recovered by rotary evaporator and residual oil was oven- dried at $60^{\circ} \mathrm{C}$ for $30 \mathrm{~min}$. The obtained oils were allowed to cold to room temperature before analysis ${ }^{[13]}$.

Calculation using the equation:-

Yield $\%$ of oil $=$ Mass of oil/ Mass of sample $\times 100 \%$.

\section{Chemical characters of the oil}

\section{Acid value}

The acid value was determined according to the method of ISO 660:1996. Ten grams of oil were dissolved in $50 \mathrm{ml}$ of the solvent and titrated against $0.1 \mathrm{~N}$ sodium hydroxide with continuous shaking using phenolphthalein as an indicator until pink color appear.

The acid value was calculated as follows:

Acid value $\left(\mathrm{mg} \mathrm{KOHg}^{-1}\right)=\frac{(v-b)}{W} \times \underline{N} \times \underline{56.1}$

Where: $56.1=$ molecular weight of potassium hydroxide $(\mathrm{g} / \mathrm{mol}) ; \mathrm{V}=$ Volume in $\mathrm{mL}$ of standard potassium hydroxide used for sample titration; $\mathrm{b}=$ Volume in $\mathrm{mL}$ of standard potassium hydroxide used for blank titration; $\mathrm{N}=$ Normality of the potassium hydroxide solution; and $\mathrm{W}=$ Weight in $\mathrm{g}$ of the sample ${ }^{[14]}$.

\section{Saponification value}

About $2.0 \mathrm{~g}$ of sample were weighed in a $200 \mathrm{ml}$ conical flask, $20 \mathrm{~mL}$ of $0.5 \mathrm{~mol} / \mathrm{L}$ alcoholic potassium hydroxide was added. The flask was gently heated and occasionally shaken for 30 minutes and cooled. The unreacted $\mathrm{KOH}$ was then back-titrated with $0.5 \mathrm{~mol} / \mathrm{L} \mathrm{HCl}$. A blank titration was performed ${ }^{[15]}$.

The saponification value (SV) in $\mathrm{mg} / \mathrm{g}$ was calculated $\underline{(B-v)} \times \underline{M} \times \underline{56.1}$ 
$W$

Where: $B=$ blank titre volume $(\mathrm{mL}) ; V=$ Sample titre volume $(\mathrm{mL}) ; M=$ molarity of the $\mathrm{HCl}$; $56.1=$ the molecular weight of $\mathrm{KOH} ; W=$ weight of sample $(\mathrm{g})$.

\section{Peroxide value}

About $5 \mathrm{~g}$ of the sample were added to $30 \mathrm{~mL}$ of the solvent mixture (acetic acid: chloroform, $2: 1 \mathrm{v} / \mathrm{v}) 5 \mathrm{~mL}$ of saturated potassium iodide were added; the mixture was gently shaken and boiled for one minute. The flask left at room temperature in dark, $30 \mathrm{~mL}$ of distilled water were added, and the flask sealed and stirred. Few drops of the starch solution were added to the mixture and the latter was titrated with $0.01 \mathrm{~N}$ Na2S2O3 solution. A blank titration was performed ${ }^{[16]}$. The peroxide value, expressed as mille equivalent of peroxide oxygen per $\mathrm{kg}$ sample (meq $/ \mathrm{kg})$, was calculated using equation

Peroxide value of the sample $(\mathrm{Meq} / \mathrm{kg})=\frac{(A-B) \times N \times 100}{W}$

Where: $A=$ volume $(\mathrm{mL})$ of $\mathrm{Na} 2 \mathrm{~S} 2 \mathrm{O} 3$ solution consumed in sample titration; $B=$ volume $(\mathrm{mL})$ of

$\mathrm{Na} 2 \mathrm{~S} 2 \mathrm{O} 3$ solution consumed in blank titration; $N=$ Normality of sodium thiosulphate solution, $w$ $=$ weight of the sample $(\mathrm{g})^{[16]}$.

\section{Iodine value}

One gram of oil was accurately weighed and placed in a dry bottle. Twenty $\mathrm{ml}$ of carbon tetrachloride from a dry measuring cylinder was used to dissolve the oil. The content was mixed and exactly $25 \mathrm{ml}$ of wijs solution from a pipette was added. And allowed to stand in dark for 30 minutes. Twenty $\mathrm{ml}$ of $0.1 \mathrm{~N}$ potassium iodide solution was added. The solution was swirled and titrated carefully with $0.1 \mathrm{~N}$ sodium thiosulphate solution. With continuous shaking. Two ml of starch solution was added and the titration was continued. Until the endpoint was reached when the blue color disappeared:

Iodine value $=(\mathrm{B}-\mathrm{A}) \times 12.69 \times \mathrm{N} / \mathrm{W}$

Where:

B: Volume (ml) of $0.1 \mathrm{~N}$ sodium thiosulphate used in blank

A: Volume $(\mathrm{ml})$ of $0.1 \mathrm{~N}$ sodium thiosulphate used in blank

$\mathrm{W}$ : Weight of oil in $(\mathrm{g})^{[17]}$

\section{Physical characters of the oil}

\section{Refractive index}

The refractive index of oils was determined by the Abbe 60 Refract meter. After calibration of the instrument, few drops of the oil were placed between the prisms of the refract meter in such a way that the space between the prisms was completely filled. The oil was then allowed to assume the temperature of the prisms $32=2 \mathrm{C}$. The refractive index was then read ${ }^{[18]}$.

\section{Relative density}




\section{4 | International Journal of Scientific and Management Research 4(5) 1-29}

The relative density was determined according to the method ${ }^{[19]}$. The relative density of the liquid (specific gravity) is the weight of a given volume of the liquid at the specified temperature, compared with the weight of an equal volume of water at the same temperature. All weighing being taken in the air ${ }^{[19]}$.

\section{Viscosity}

The viscosity of the oil samples was determined by using Ostwald-U- tube viscometer according to the method ${ }^{[20]}$.

Calculations:

Relative viscosity of the oil $=\mathrm{T}-\mathrm{T} 0 / \mathrm{T} 0$

Where:

T: flow time of the oil (sec)

T0: flow time of the distilled water (sec).

\section{Sample Preparation}

Mixed thoroughly $2 \mathrm{ml}$ of the sample with $7 \mathrm{ml}$ of alcoholic sodium hydroxide $(\mathrm{NaOH})$ that was prepared by dissolving $2 \mathrm{~g}$ in $100 \mathrm{ml}$ methanol. $7 \mathrm{ml}$ of alcoholic sulfuric acid $\left(1 \mathrm{ml}_{2} \mathrm{SO}_{4}\right.$ to $100 \mathrm{ml}$ methanol) was then added. Shaking the mixture for 5 minutes. Then the content of the test tube was left to stand overnight. $1 \mathrm{ml}$ of Supersaturated sodium chloride $(\mathrm{NaCl})$ was then added and the contents being shaken. Add $2 \mathrm{ml}$ of normal hexane and the contents were shaking thoroughly for three minutes. Then the upper layer of the test tube (n-hexane layer) was taken using a disposable syringe. Diluted $5 \mu \mathrm{l}$ from the $\mathrm{n}$-hexane extract with $5 \mathrm{ml}$ of diethyl ether. Then filter the mixture through a syringe filter $0.45 \mu \mathrm{m}$ and use anhydrous sodium sulphate as drying agent, $1 \mathrm{~g}$ of it.1 $\mu \mathrm{l}$ of the diluted sample was injected in the GC.MS instrument.

\section{Method of analysis:}

\section{GC/MS Conditions}

GM/MS technique was used to determine the qualitative and quantitative analysis of the sample, model (GC/MS-QP2010-Ultra) from japans 'Simadzu Company, the serial number $020525101565 \mathrm{SA}$ and capillary column (Rtx-5ms-30m $\times 0.25 \mathrm{~mm} \times 0.25 \mu \mathrm{m})$. The injection of the sample by using the split mode, the carrier gas was helium passed with flow rate $1.61 \mathrm{ml} / \mathrm{min}$, the program of temperature was started from $60 \mathrm{c}$ with rate $10 \mathrm{c} / \mathrm{min}$ to $300 \mathrm{c}$ as final temperature degree with 3 minutes hold time, the ion source temperature was 200c, the injection port temperature was $300 \mathrm{c}$, and the interface temperature was $250 \mathrm{c}$. The analyzed sample by using scan mode in the range of $\mathrm{m} / \mathrm{z} 40-500$ charges to ratio and the total run time was 27 minutes. Identification of constituents for the sample was achieved by comparing their mass fragmentation patents and retention index and with those present in the library, the National Institute of Standards and Technology (NIST), , results were recorded.

Atomic Absorption Spectrophotometer (AA-7000-Shimadzu).

\section{Results and Discussion}

The amount of the flaxseed oil obtained were 38\%, this result agrees with ${ }^{[21]}$ recorded a percentage of flaxseed oil was $35.10 \%$, this variation in the extraction percentages can be due to 


\section{5 | International Journal of Scientific and Management Research 4(5) 1-29}

the differences soil, differences in species of the plant and diversity of climate. The physicochemical properties of extracted flaxseed oil were investigated and the results obtained were shown in Table 1 . chemical properties such as acid value $(0.71 \mathrm{mg} \mathrm{KOH} / \mathrm{g})$ as oleic acid, the acid value is a measure of the free fatty acids content in oil, peroxide value (2.69 MEG $\mathrm{O} 2 / \mathrm{KG}$ ) a widely used test forgives an idea about the early stages of oil oxidation and detect the rancidity in oils, saponification value $(186.50 \mathrm{mg} \mathrm{KOH} / \mathrm{g}$ oil), a high saponification value of the oil can be used in soap making. and iodine value $(96.67 \mathrm{~g} / 100$ which is considered as one of the parameters used to determine the quality of the oil, refers to the presence of unsaturated fatty acids in oils, which reflects the susceptibility of oil to oxidation. these obtained results were agree with the result obtained by ${ }^{[21,22,23,24,25]}$. Table. 2 show the Physical properties such as density $(0.91 \mathrm{~g} / \mathrm{cm} 3)$, refractive index $\left(1.39\right.$ and at $\left.28^{\circ} \mathrm{C}\right)$, viscosity $(\mathrm{cSt})(68.33)$ these results agree with ${ }^{[21,22,23]}$.Table.3 and figure(1-26) show the chemical constituents obtained by Gas Chromatography-Mass Spectrometry (GC-MS) it contained 26 compounds identified, the major compound are, 9-Octadecenoic acid (Z)-, methyl ester (Oleic acid) (43.72) act as antioxidant, anti-cancer, Hexadecanoic acid, methyl ester (Palmitic acid) (17.36) act as Anti-oxidants, decrease blood cholesterol, anti-inflammatory, 9,12,15-Octadecatrienoic acid, methyl ester, $(\mathrm{Z}, \mathrm{Z}, \mathrm{Z})$ fatty acids: $\alpha$-Linolenic acid, an omega-3 $(\mathrm{n}-3)$ fatty acid $\gamma$-Linolenic acid, an omega$\underline{6}$ (n-6) fatty acid (15.72), Octadecanoic acid Methyl stearate (13.13) used As a food additive, soaps, cosmetics, detergents lubricants, softening and release agents,13-Docosenoic acid, methyl ester, (Z)-(1.31), cis-11-Eicosenoic acid, methyl ester (0.96) act as Antibacterial, antitumor, antifungal, cytotoxic ${ }^{[26,27,28,29,30]}$. Table. 4 how Atomic absorption used to identify minerals content it contains Calcium 1180ppm, Copper 4.1ppm, Ferric 15.7ppm, Zinc 34.58ppm.

Tables and figures of flaxseed oil

Table.1.Chemical properties of flaxseed

\begin{tabular}{|l|l|}
\hline Acid value (mg KOH/g oil) & $0.71 \mathrm{mg} \mathrm{KOH} / \mathrm{g}$ \\
\hline Saponification value $(\mathrm{mg} \mathrm{KOH} / \mathrm{g}$ oil) & $186.50 \mathrm{mg} \mathrm{KOH} / \mathrm{g}$ oil \\
\hline Peroxide value (meq O2/kg) & $2.69 \mathrm{meq} \mathrm{O} / \mathrm{kg}$ \\
\hline Iodine value $(\mathrm{g} / 100 \mathrm{~g})$ & $96.67 \mathrm{~g} / 100 \mathrm{~g}$ \\
\hline
\end{tabular}

Table.2. Physical properties of flaxseed

\begin{tabular}{|l|l|}
\hline Density $\left(\mathrm{g} / \mathrm{cm}^{3}\right)$ & $0.91 \mathrm{~g} / \mathrm{cm}^{3}$ \\
\hline viscosity $(\mathrm{cSt})$ & 68.33 \\
\hline Refractive index & 1.39 and at $28^{\circ} \mathrm{C}$ \\
\hline
\end{tabular}


6 | International Journal of Scientific and Management Research 4(5) 1-29

Table. 3. Chemical constituents of flaxseed obtained by Gas Chromatography-Mass Spectrometry (GC-MS)

\begin{tabular}{|c|c|c|c|c|}
\hline & Name & Ret.Time & Area & Area\% \\
\hline 1. & Methyl tetradecanoate & 13.289 & 916164 & 0.19 \\
\hline 2. & Pentadecanoic acid, methyl ester & 14.360 & 344674 & 0.07 \\
\hline 3. & 7-Hexadecenoic acid, methyl ester, (Z)- & 15.151 & 328194 & 0.07 \\
\hline 4. & 9-Hexadecenoic acid, methyl ester, (Z)- & 15.191 & 1043203 & 0.21 \\
\hline 5. & Hexadecanoic acid, methyl ester & 15.408 & 84377342 & 17.36 \\
\hline 6. & cis-10-Heptadecenoic acid, methyl ester & 16.155 & 668876 & 0.14 \\
\hline 7. & Heptadecanoic acid, methyl ester & 16.365 & 1226357 & 0.25 \\
\hline 8. & 9-Octadecenoic acid (Z)-, methyl ester & 17.140 & 212421520 & 43.72 \\
\hline 9. & 9-Octadecenoic acid (Z)-, methyl ester & 17.188 & 3666857 & 0.75 \\
\hline 10. & $\begin{array}{l}\text { 9,12,15-Octadecatrienoic acid, methyl ester, } \\
(\mathrm{Z}, \mathrm{Z}, \mathrm{Z}) \text { - }\end{array}$ & 17.240 & 76398640 & 15.72 \\
\hline 11. & Methyl stearate & 17.342 & 63802824 & 13.13 \\
\hline 12. & 11,14-Eicosadienoic acid, methyl ester & 17.904 & 175052 & 0.04 \\
\hline 13. & 11,14,17-Eicosatrienoic acid, methyl ester & 18.731 & 2130390 & 0.44 \\
\hline 14. & cis-11-Eicosenoic acid, methyl ester & 18.863 & 4655679 & 0.96 \\
\hline 15. & 8,11,14-Eicosatrienoic acid, methyl ester & 18.902 & 1328973 & 0.27 \\
\hline 16. & Eicosanoic acid, methyl ester & 19.062 & 3013673 & 0.62 \\
\hline 17. & 13-Docosenoic acid, methyl ester, (Z)- & 20.506 & 6371600 & 1.31 \\
\hline 18. & Docosanoic acid, methyl ester & 20.690 & 2565009 & 0.53 \\
\hline 19. & Octadecanoic acid, 6-hydroxy-, methyl ester & 20.783 & 2076001 & 0.43 \\
\hline 20. & 15-Tetracosenoic acid, methyl ester, (Z)- & 22.034 & 1283185 & 0.26 \\
\hline 21. & Methyl 8-oxohexadecanoate & 22.099 & 1055613 & 0.22 \\
\hline 22. & Tetracosanoic acid, methyl ester & 22.187 & 2029432 & 0.42 \\
\hline 23. & Erucic acid & 23.013 & 1568971 & 0.32 \\
\hline 24. & Hexacosanoic acid, methyl ester & 23.587 & 495770 & 0.10 \\
\hline 25. & Stigmast-5-en-3-ol, oleate & 25.072 & 1078478 & 0.22 \\
\hline 26. & $\begin{array}{l}\text { 9,19-Cyclolanost-23-ene-3,25-diol, 3-acetate, } \\
\text { (3.beta.,23E)- }\end{array}$ & 25.351 & 10948184 & 2.25 \\
\hline
\end{tabular}


7 | International Journal of Scientific and Management Research 4(5) 1-29

Table.4. Minerals of flaxseed

\begin{tabular}{|l|c|c|}
\hline No & Elements & Amount in flaxseed \\
\hline 1 & & \\
\hline 2 & Ca ppm & 1180 \\
\hline 3 & Cd ppm & NDT \\
\hline 4 & Co ppm & NDT \\
\hline 5 & Cr ppm & 4.1 \\
\hline 6 & $\mathrm{Cu} \mathrm{ppm}$ & 15.7 \\
\hline 7 & $\mathrm{Fe} \mathrm{ppm}$ & NDT \\
\hline 8 & $\mathrm{~Pb} \mathrm{ppm}$ & 34.58 \\
\hline
\end{tabular}

\section{NDT=Not Detected}

Methyl tetradecanoate \$ Tetradecanoic acid, methyl ester

Molecular weight 242. Formula C15H30O2 (Figure 1)
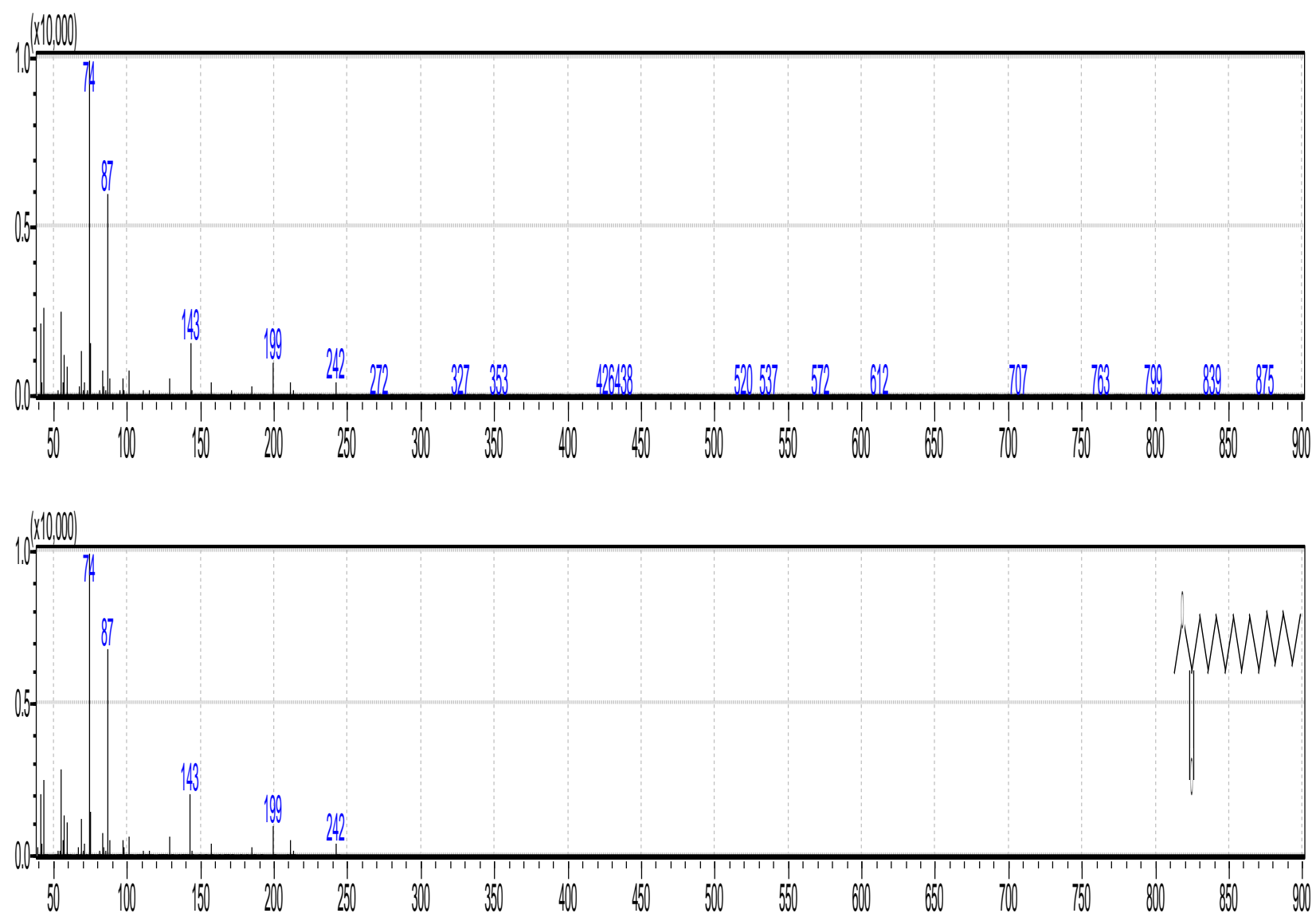

2/ Pentadecanoic acid, methyl ester 
8 | International Journal of Scientific and Management Research 4(5) 1-29

Molecular weight 256. Formula C16H32O2 (Figure2)
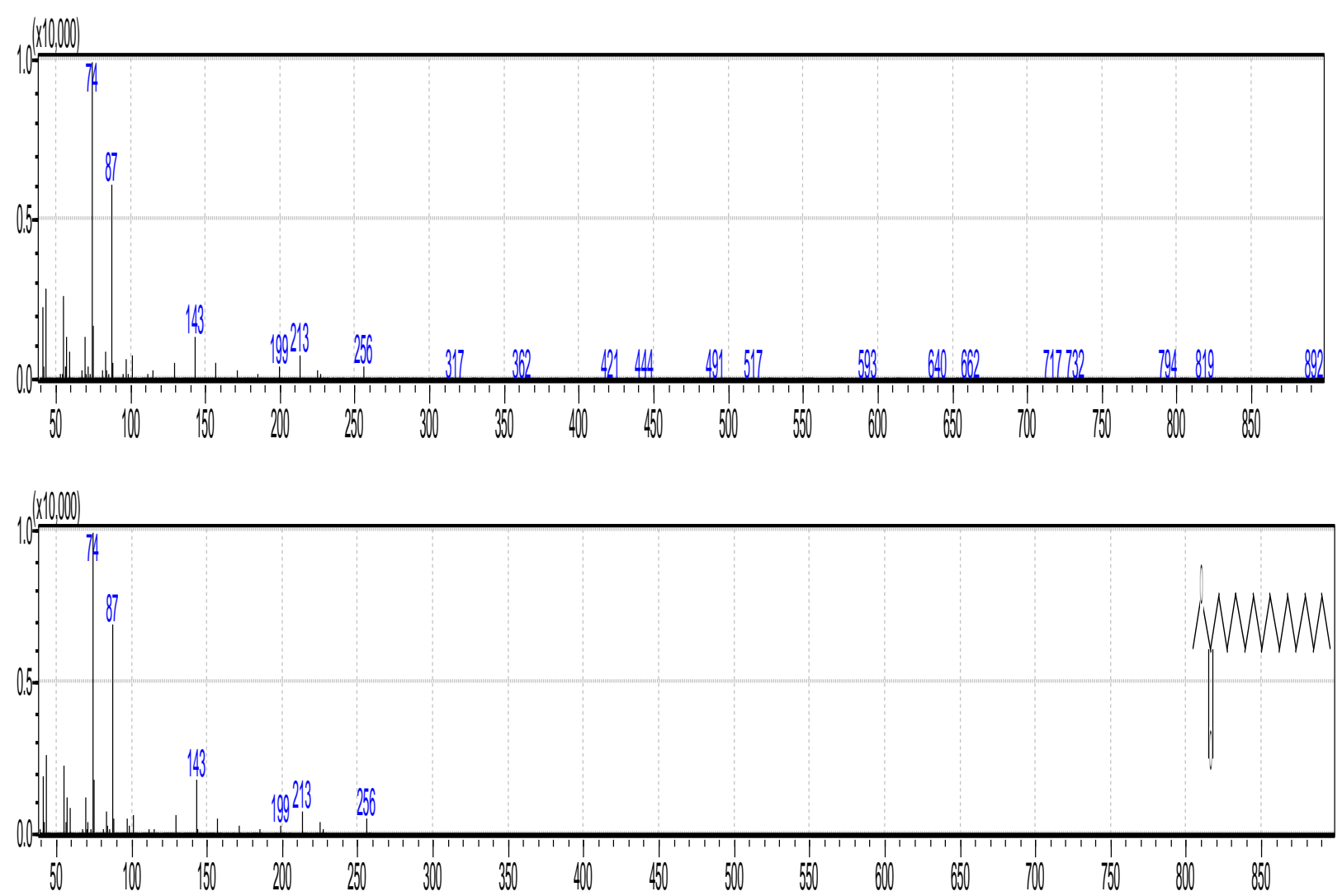

\section{3/7-Hexadecenoic acid, methyl ester, (Z)-4/}

Molecular weight 268. Formula C17H32O2 (Figure 3)

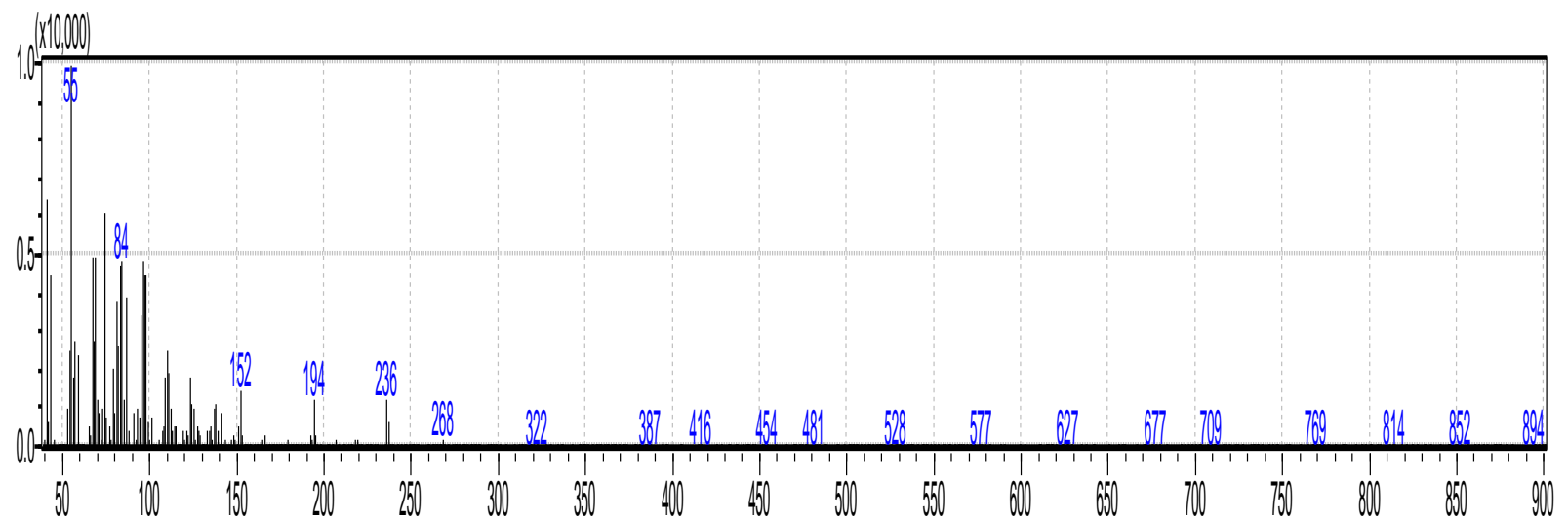


9 | International Journal of Scientific and Management Research 4(5) 1-29
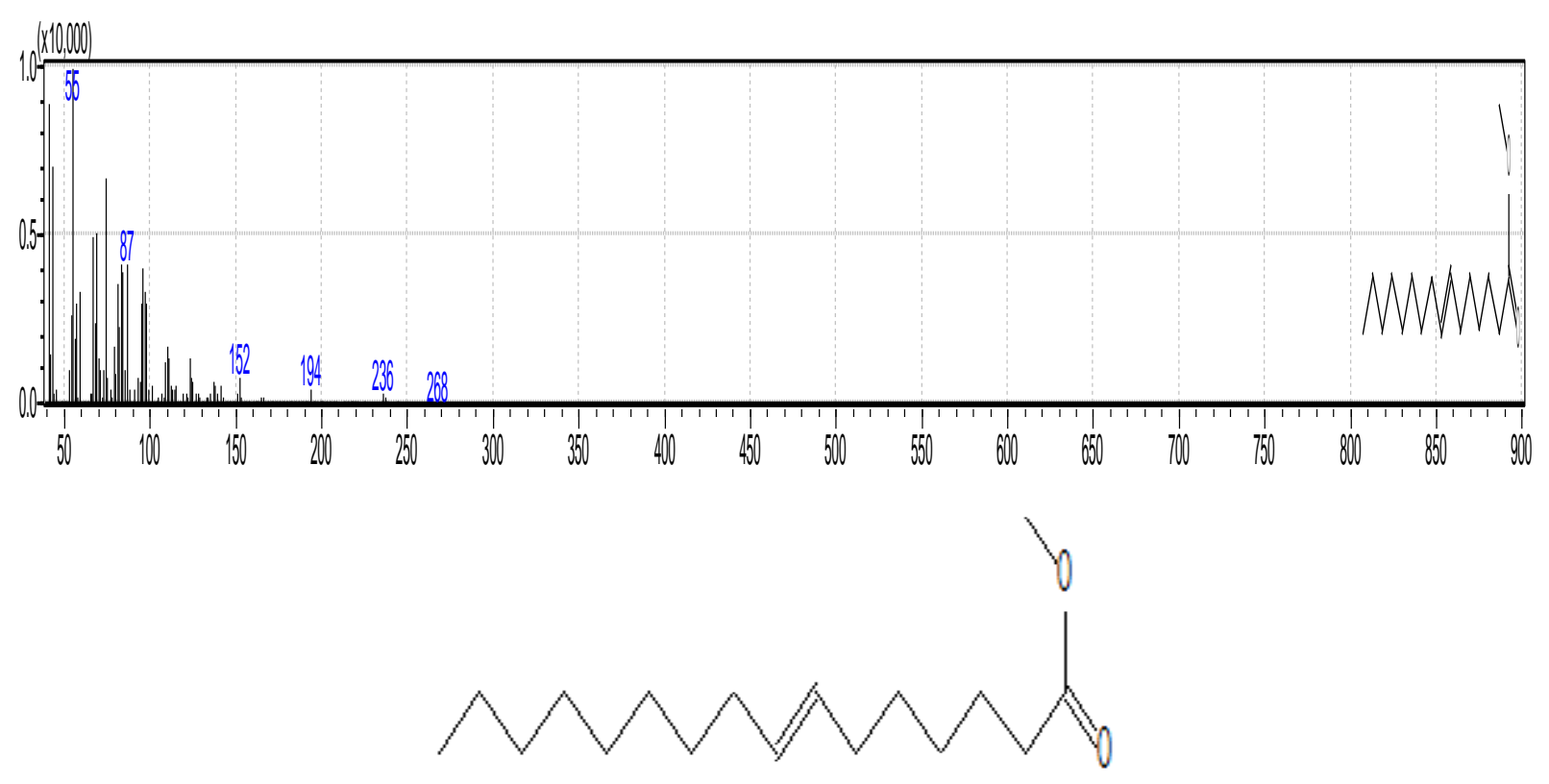

4/ 9-Hexadecenoic acid, methyl ester, (Z)- \$ Methyl palmitoleate

Molecular weight 268. Formula C17H32O2 (Figure.4.)
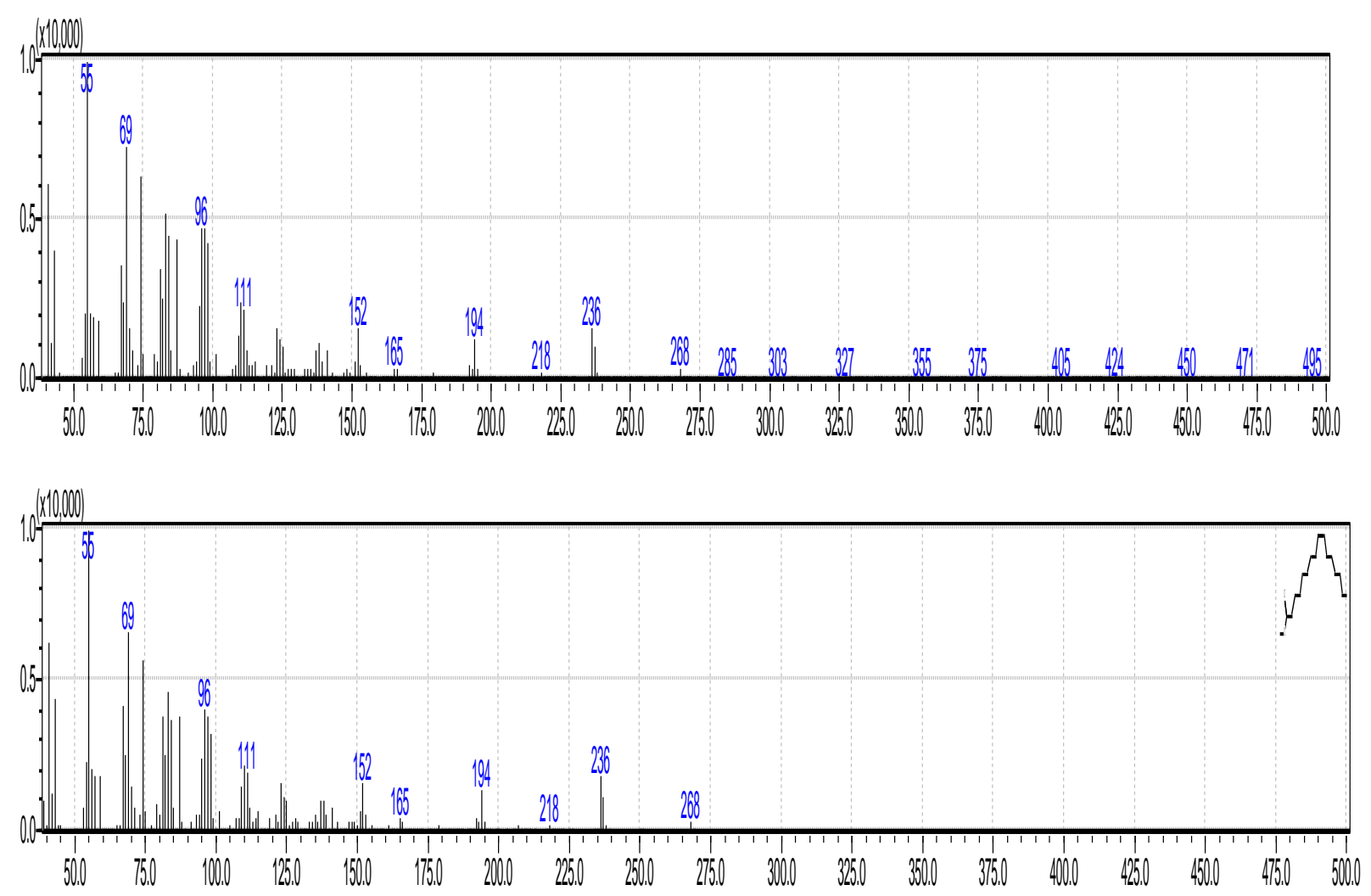
10 | International Journal of Scientific and Management Research 4(5) 1-29

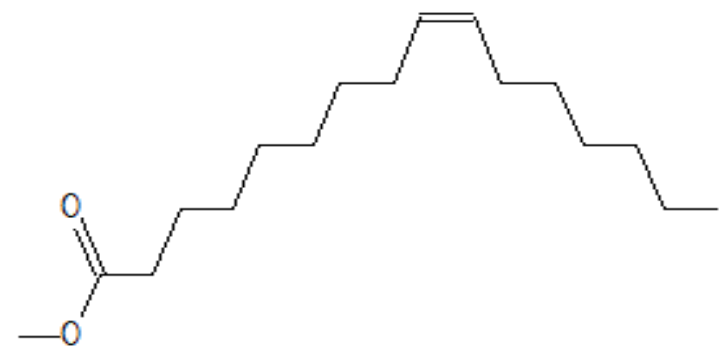

\section{5/ Hexadecanoic acid, methyl ester \$ \$ Palmitic acid, methyl ester}

Molecular weight 270. Formula C17H34O2 (Figure.5)
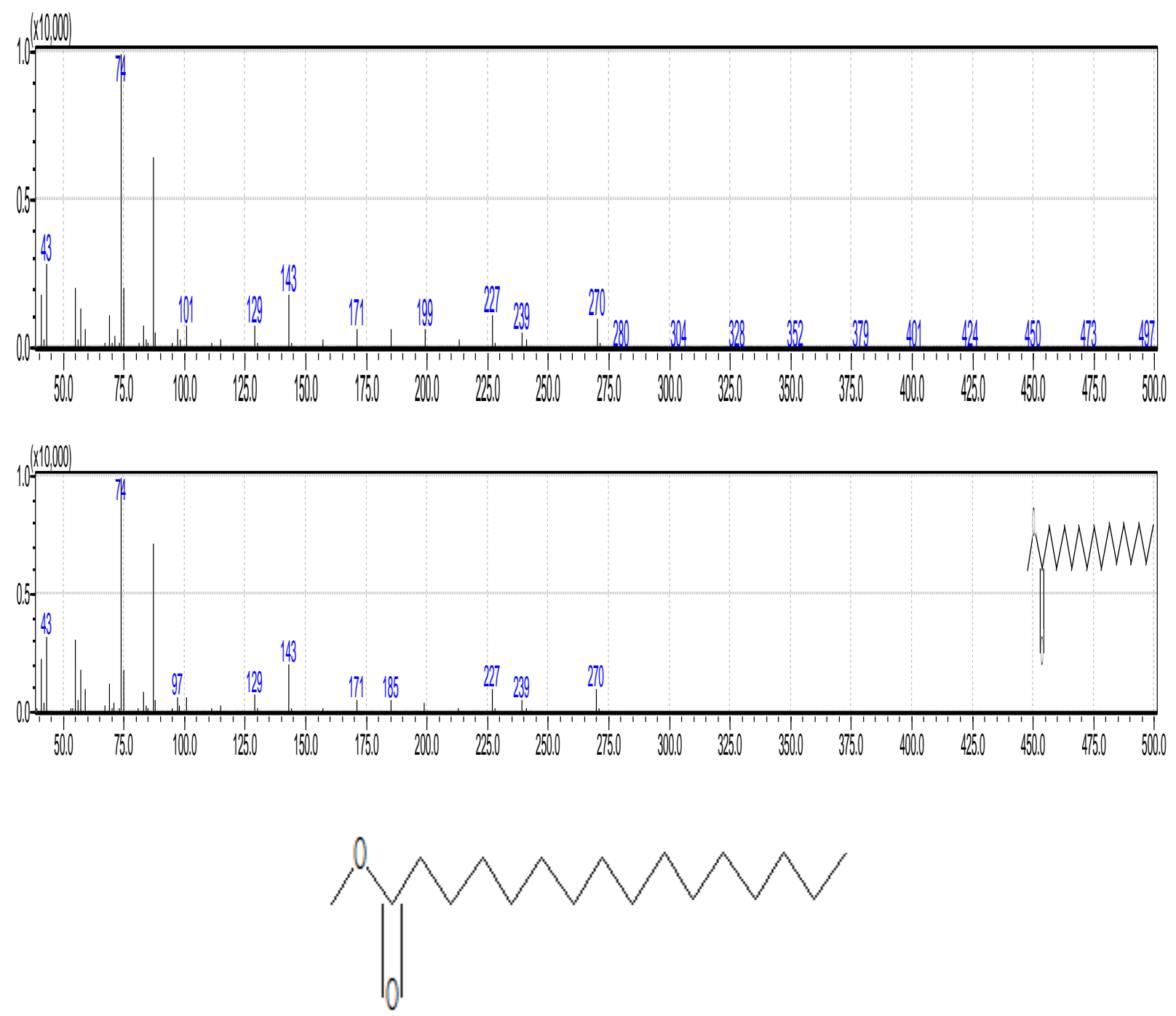

6/ cis-10-Heptadecenoic acid, methyl ester 
11 | International Journal of Scientific and Management Research 4(5) 1-29

Molecular weight 282. Formula C18H34O2 (Figure.6)
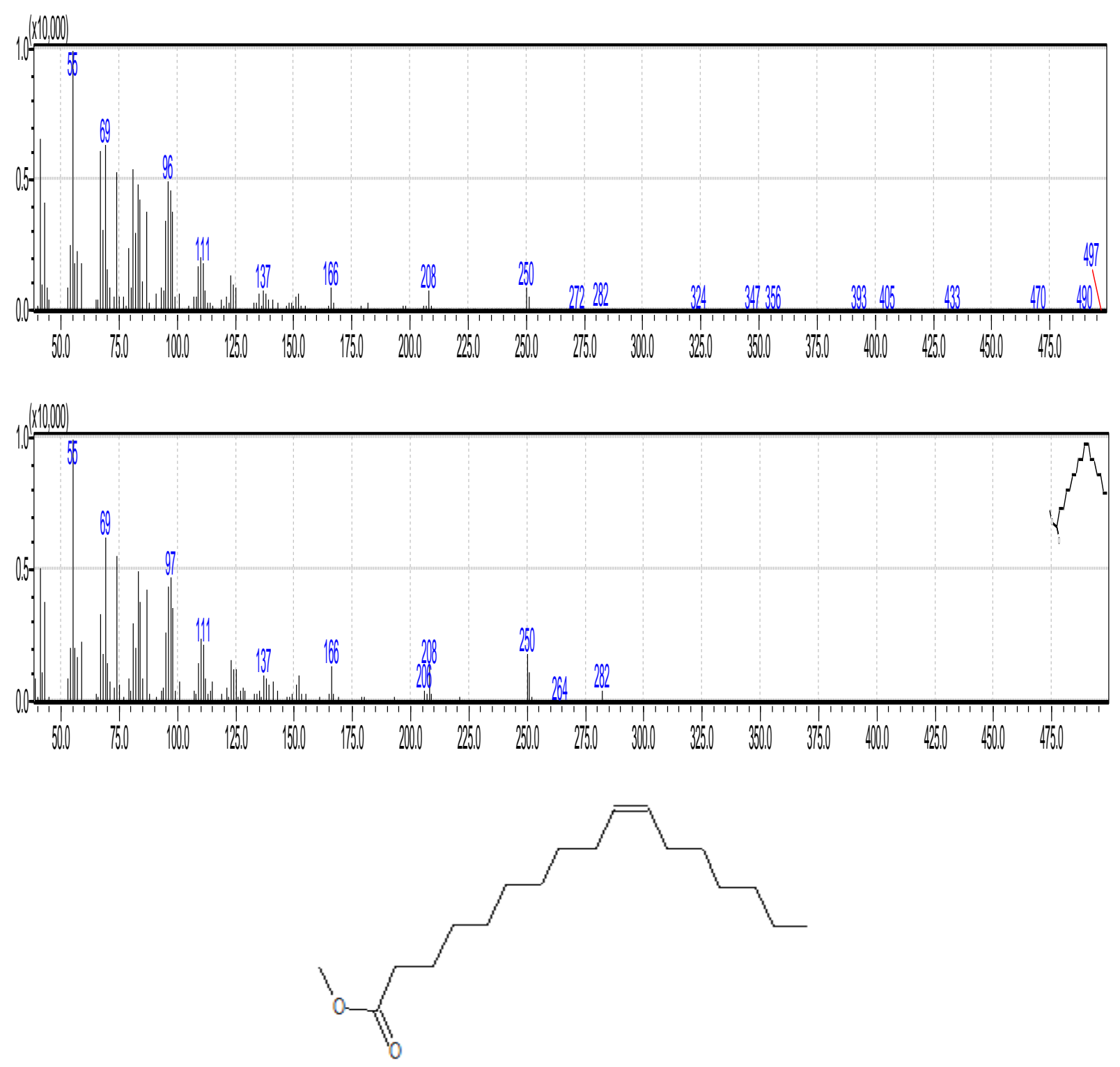

7/ Heptadecanoic acid, methyl ester \$ Margaric acid methyl ester

Molecular weight 284. Formula C18H36O2 (Figure.7) 
12 | International Journal of Scientific and Management Research 4(5) 1-29
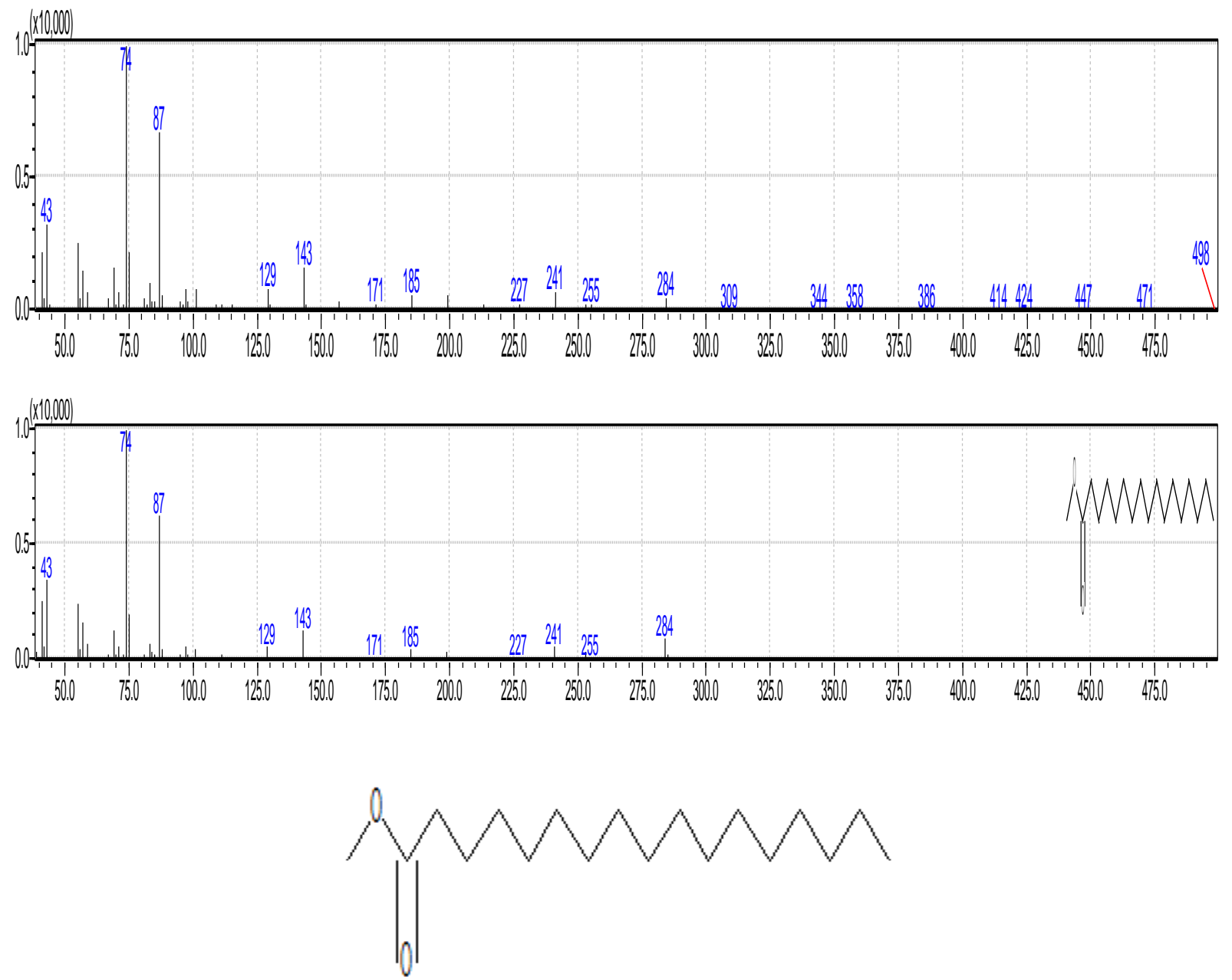

8/ 9,12-Octadecadienoic acid (Z,Z)-, methyl ester \$ Linoleic acid, methyl ester

Molecular weight 294. Formula C19H34O2 (Figure.8)

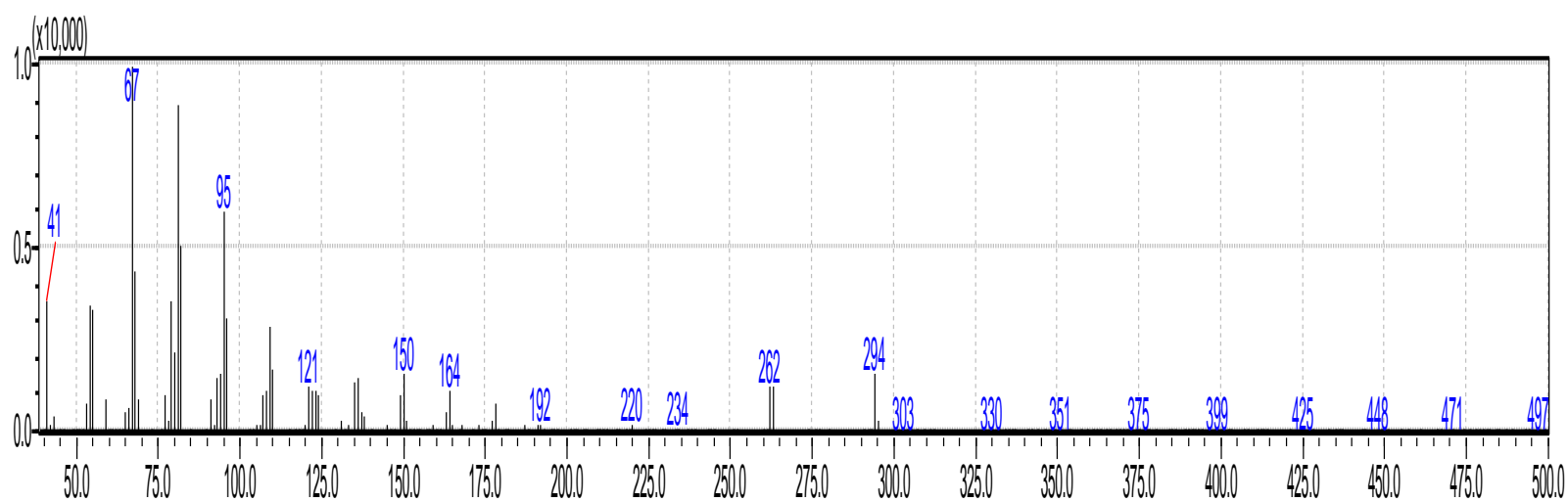


13 | International Journal of Scientific and Management Research 4(5) 1-29
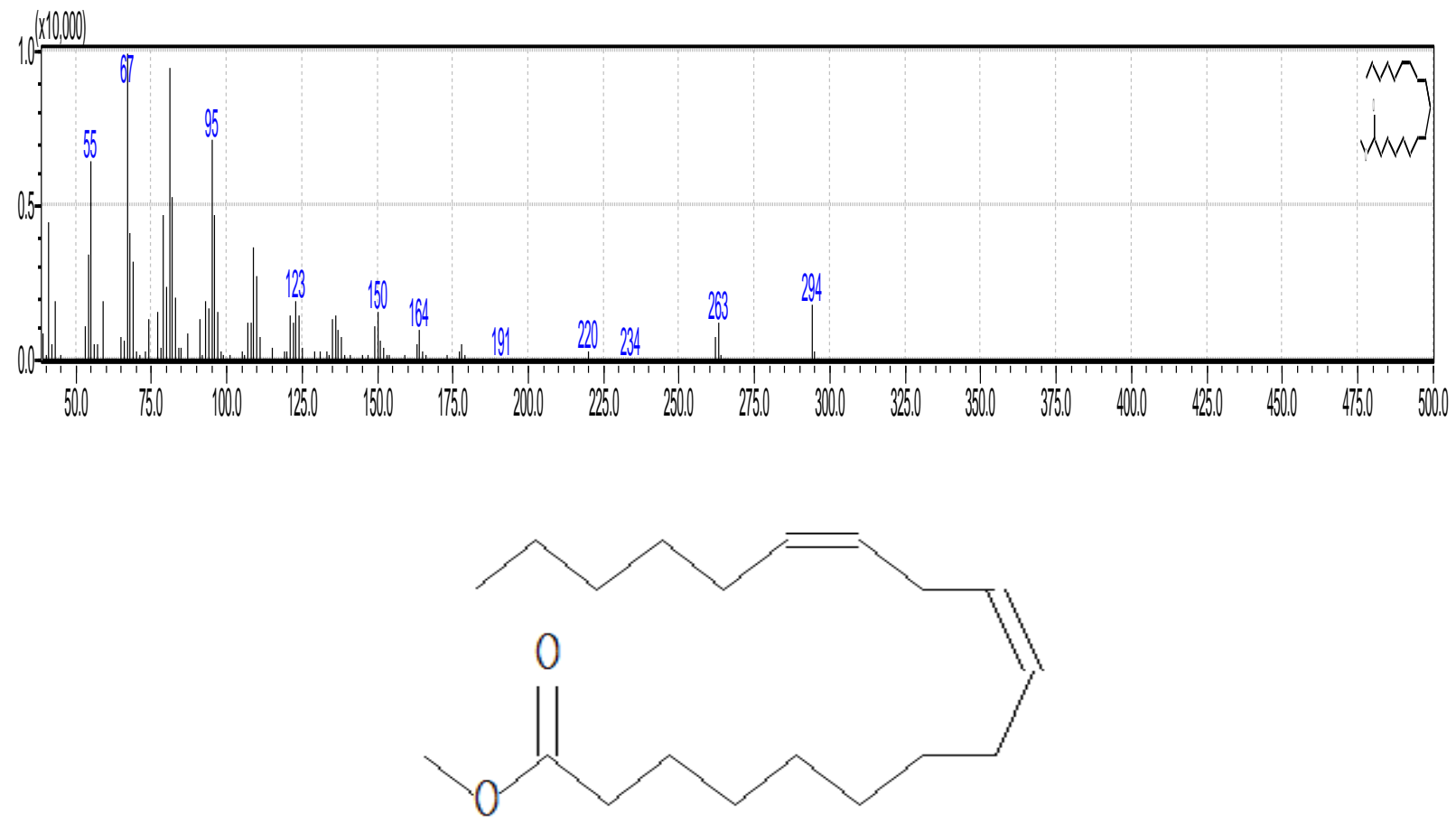

9/ 9-Octadecenoic acid (Z)-, methyl ester \$ O Oleic acid, methyl ester

Molecular weight 296. Formula C19H36O2 (Figure.9)
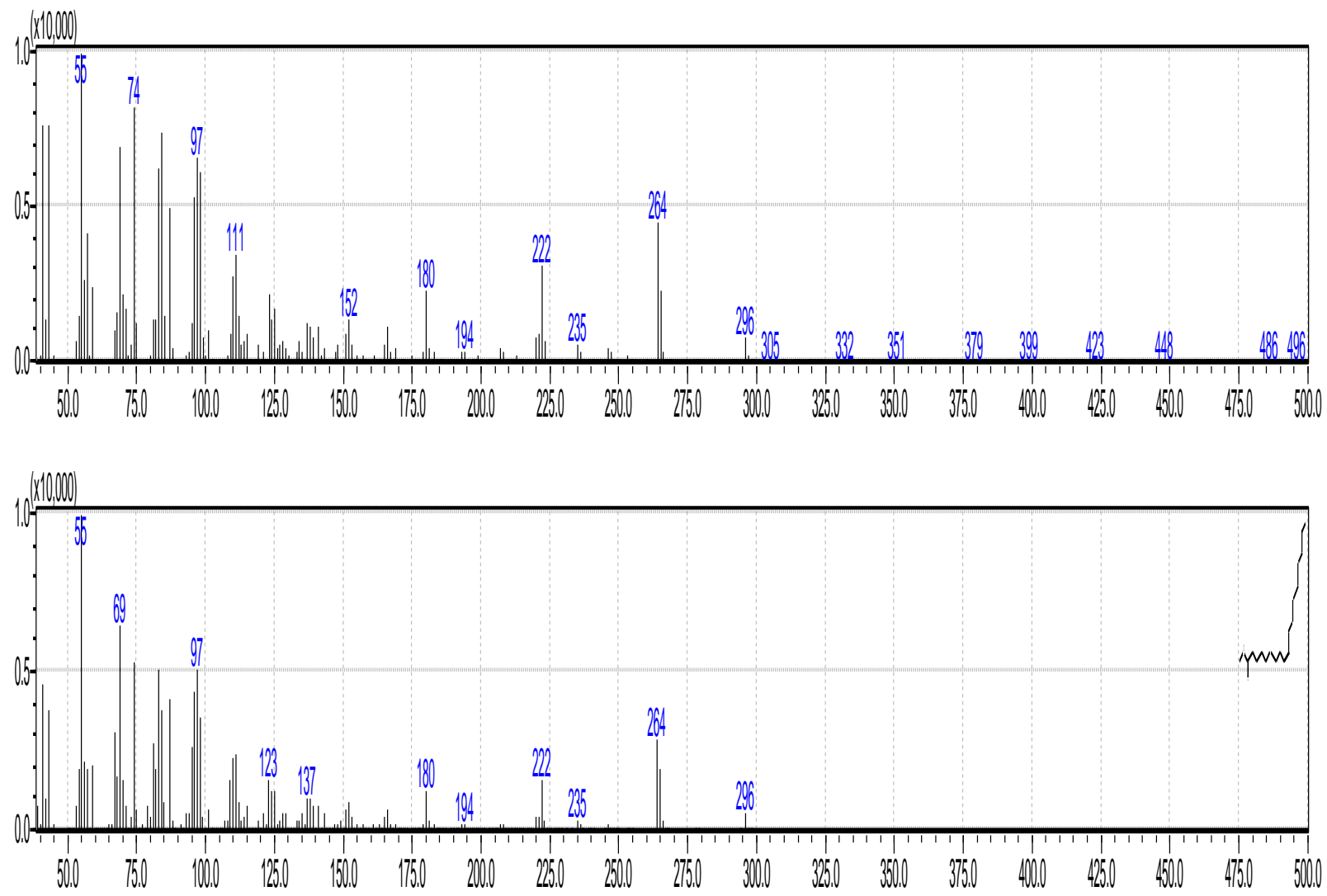


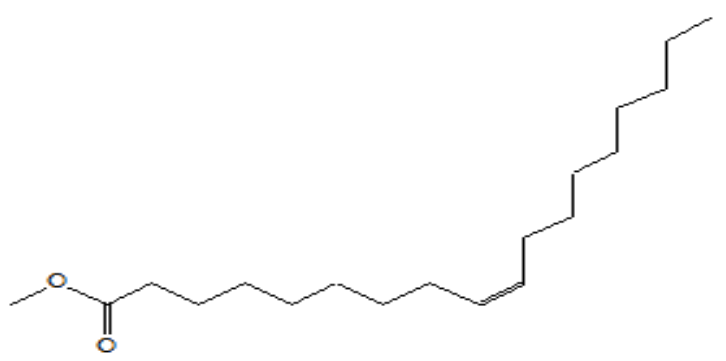

10/ 9, 12, 15-Octadecatrienoic acid, methyl ester, $(Z, Z, Z)$ - \$ Linolenic acid, methyl ester Molecular weight 292. Formula C19H32O2 (Figure.10)
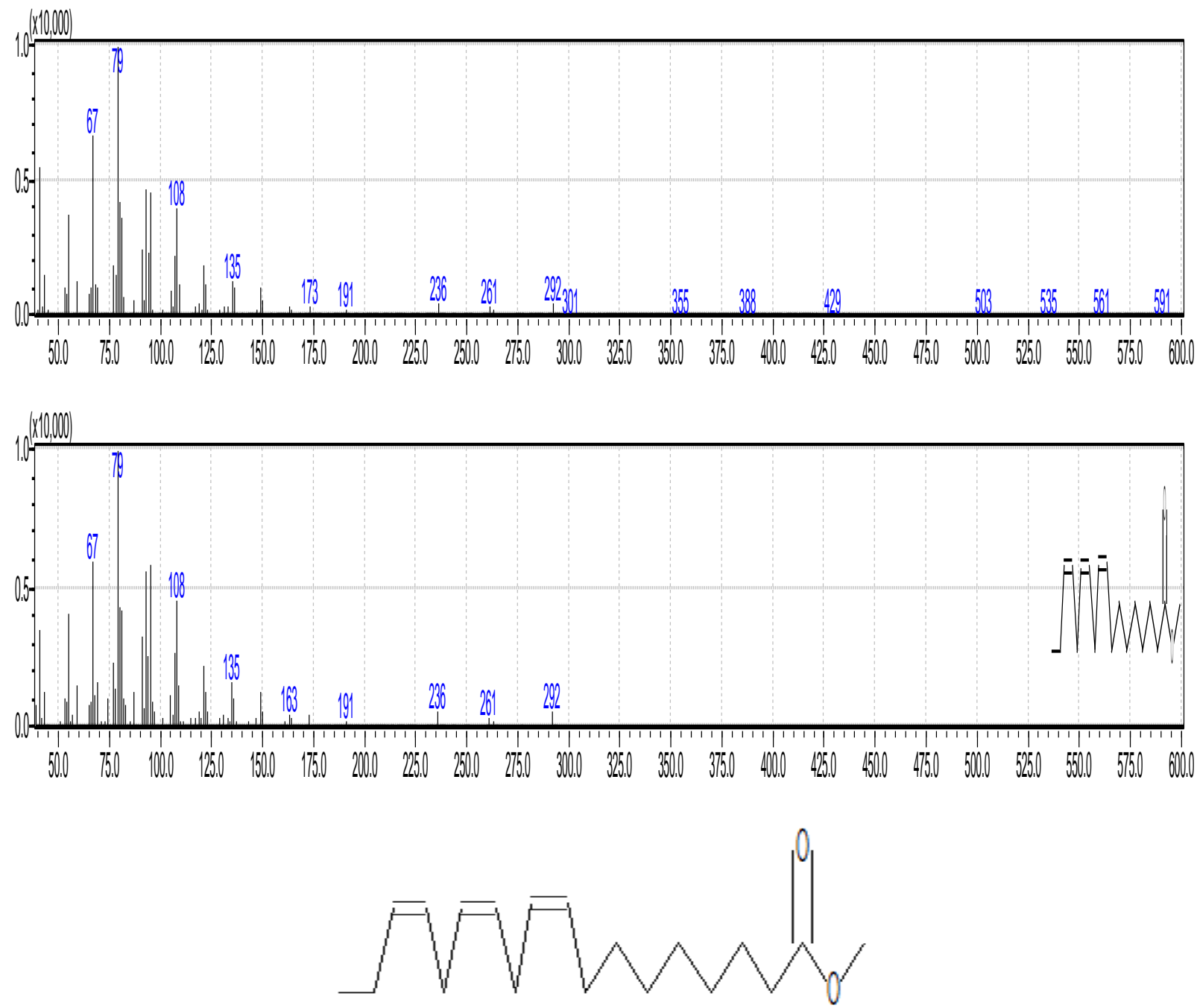

11/ Methyl stearate \$\$ Octadecanoic acid, methyl ester \$\$ Stearic acid, methyl ester Molecular weight 298. Formula C19H38O2 (Figure.11) 
15 | International Journal of Scientific and Management Research 4(5) 1-29
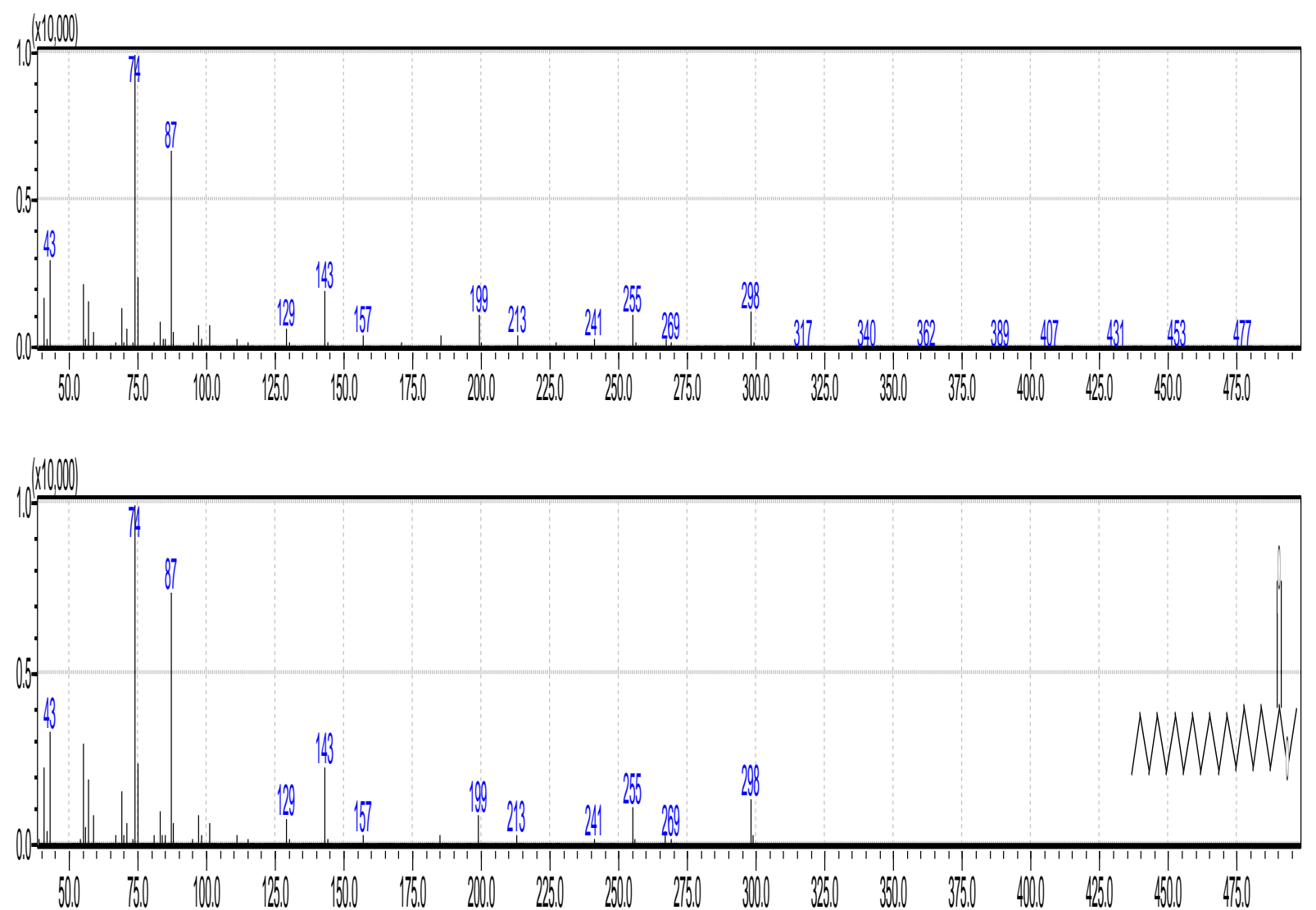

\section{2/ 11, 14-Eicosadienoic acid, methyl ester}

Molecular weight 322. Formula C21H38O2 (Figure.12)

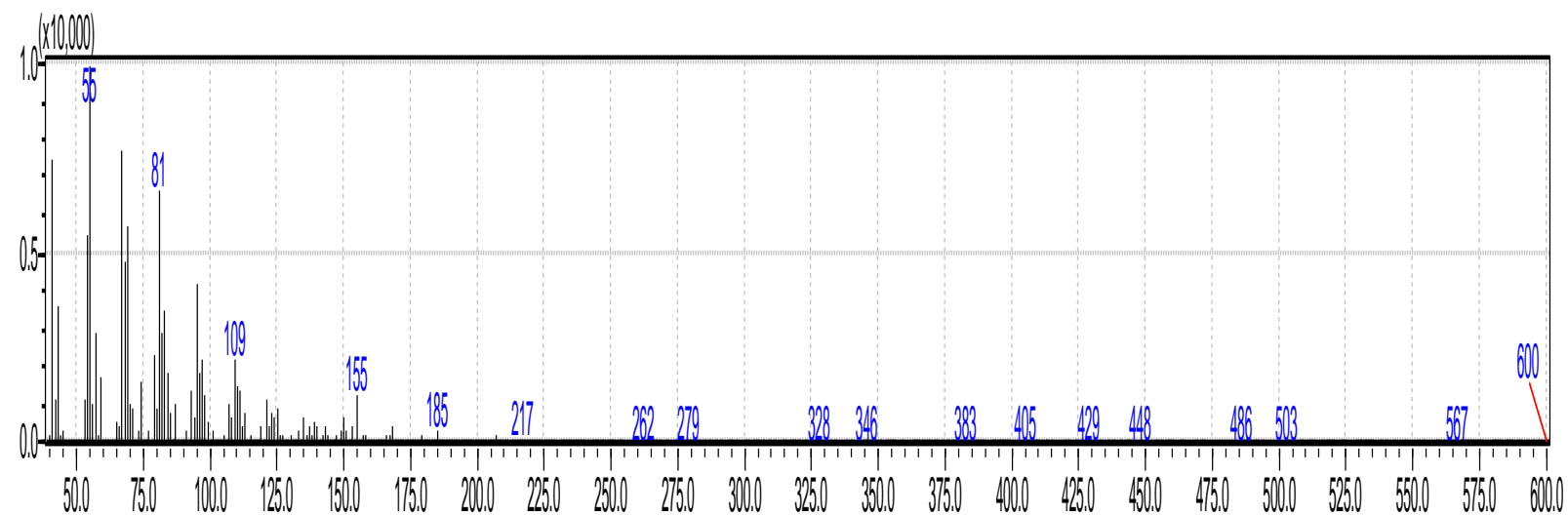


16 | International Journal of Scientific and Management Research 4(5) 1-29
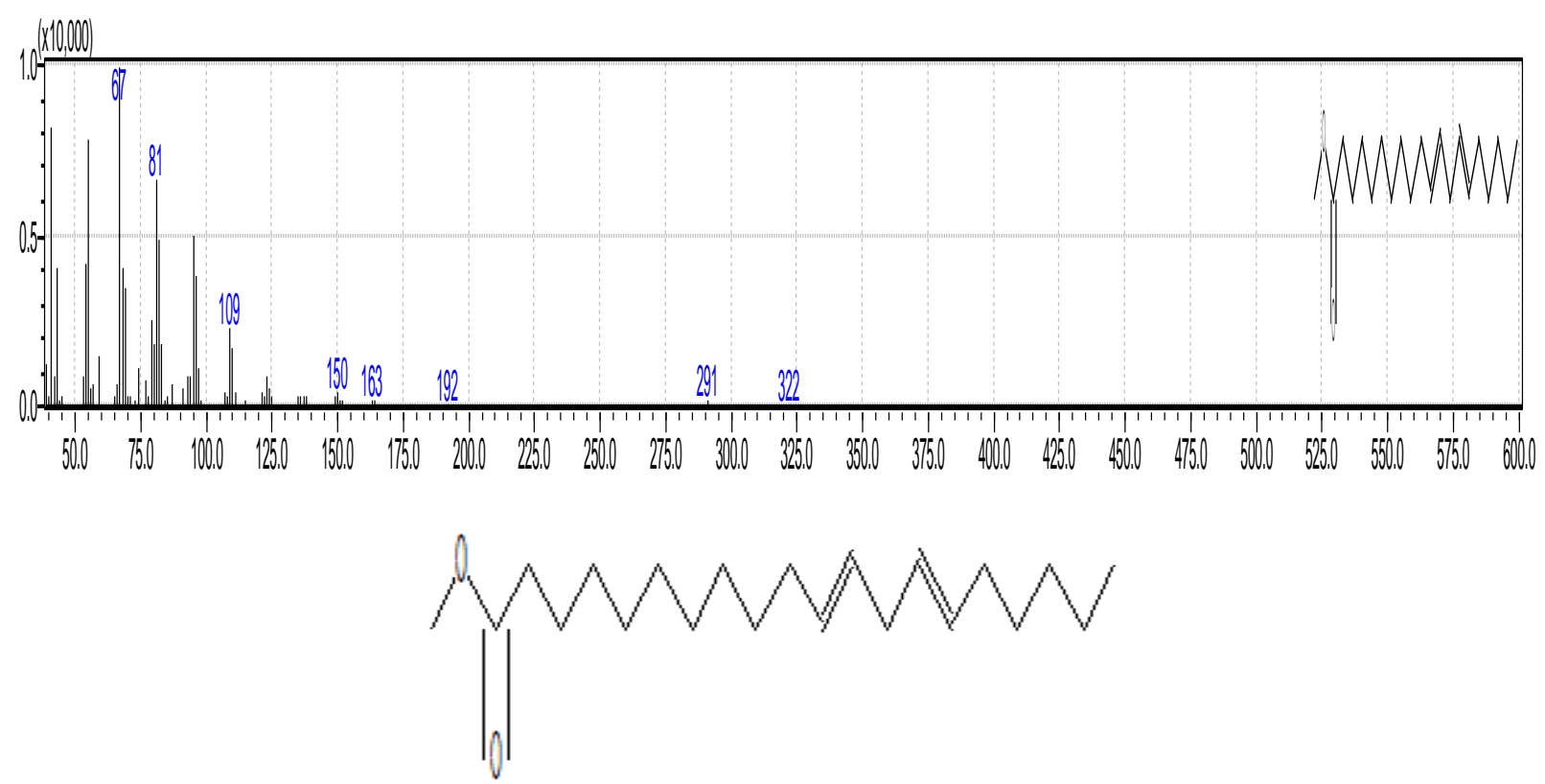

\section{3/ 11, 14, 17-Eicosatrienoic acid, methyl ester}

Molecular weight 320. Formula C21H36O2 (Figure13)
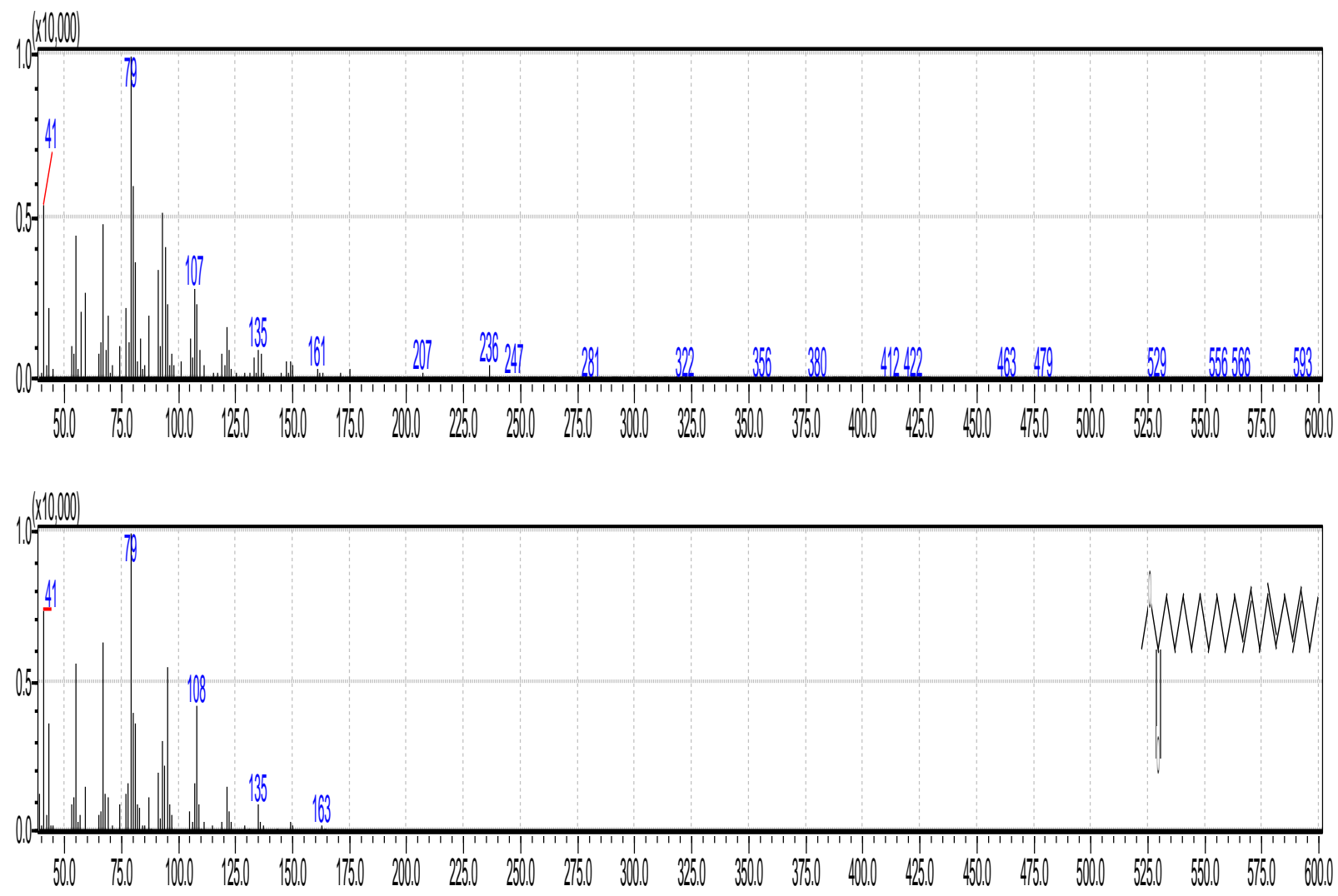
17 | International Journal of Scientific and Management Research 4(5) 1-29

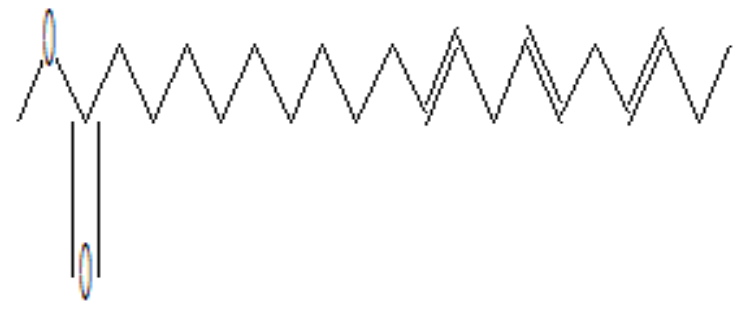

14/ cis-11-Eicosenoic acid, methyl ester

Molecular weight 324. Formula $\mathrm{C} 21 \mathrm{H} 40 \mathrm{O} 2$ (Figure.14)
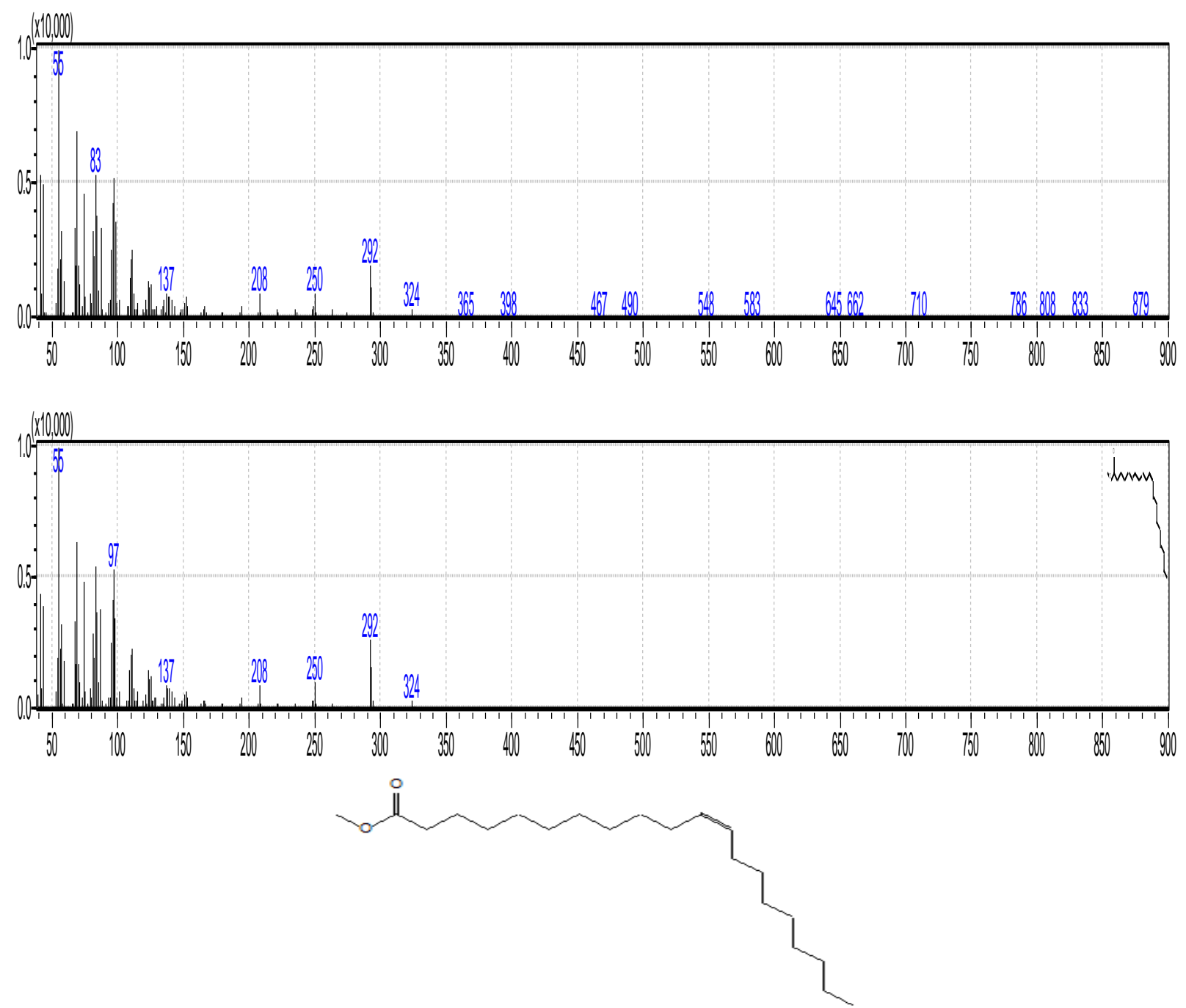

15/ 8, 11, 14-Eicosatrienoic acid, methyl ester

Molecular weight 320. Formula C21H36O2 (Figure.15) 
18 | International Journal of Scientific and Management Research 4(5) 1-29
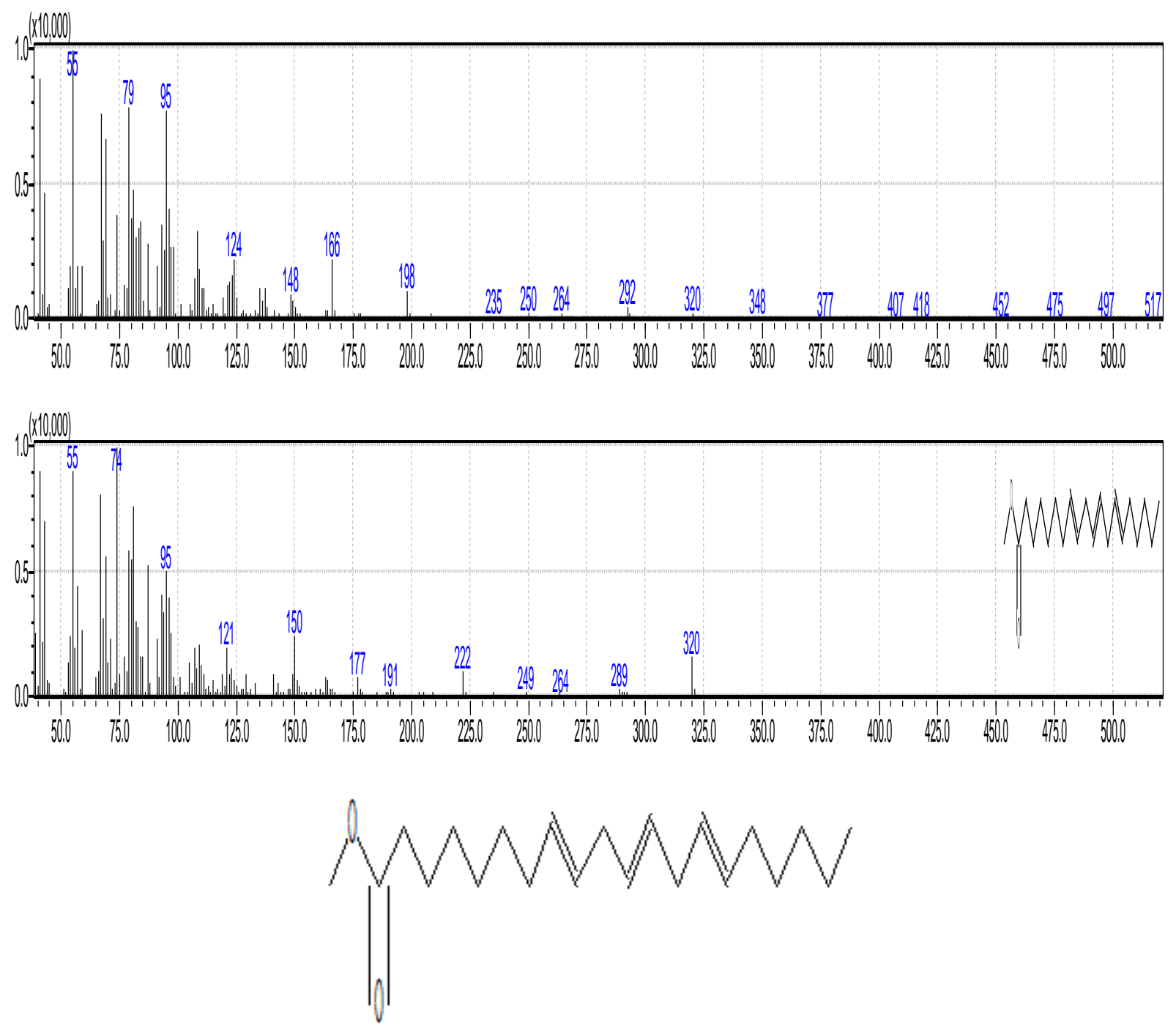

16/ Eicosanoic acid, methyl ester \$ Methyl arachisate \$ Methyl eicosanoate \$ Arachidic acid methyl ester

Molecular weight 326. Formula C21H42O2 (Figure.16)

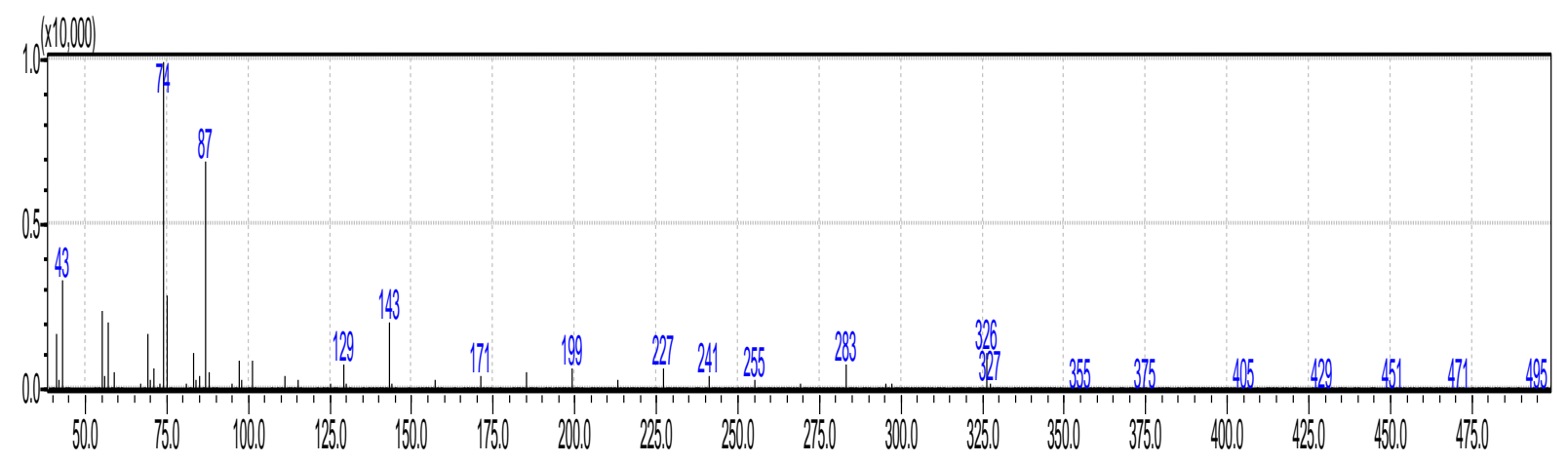


19 | International Journal of Scientific and Management Research 4(5) 1-29

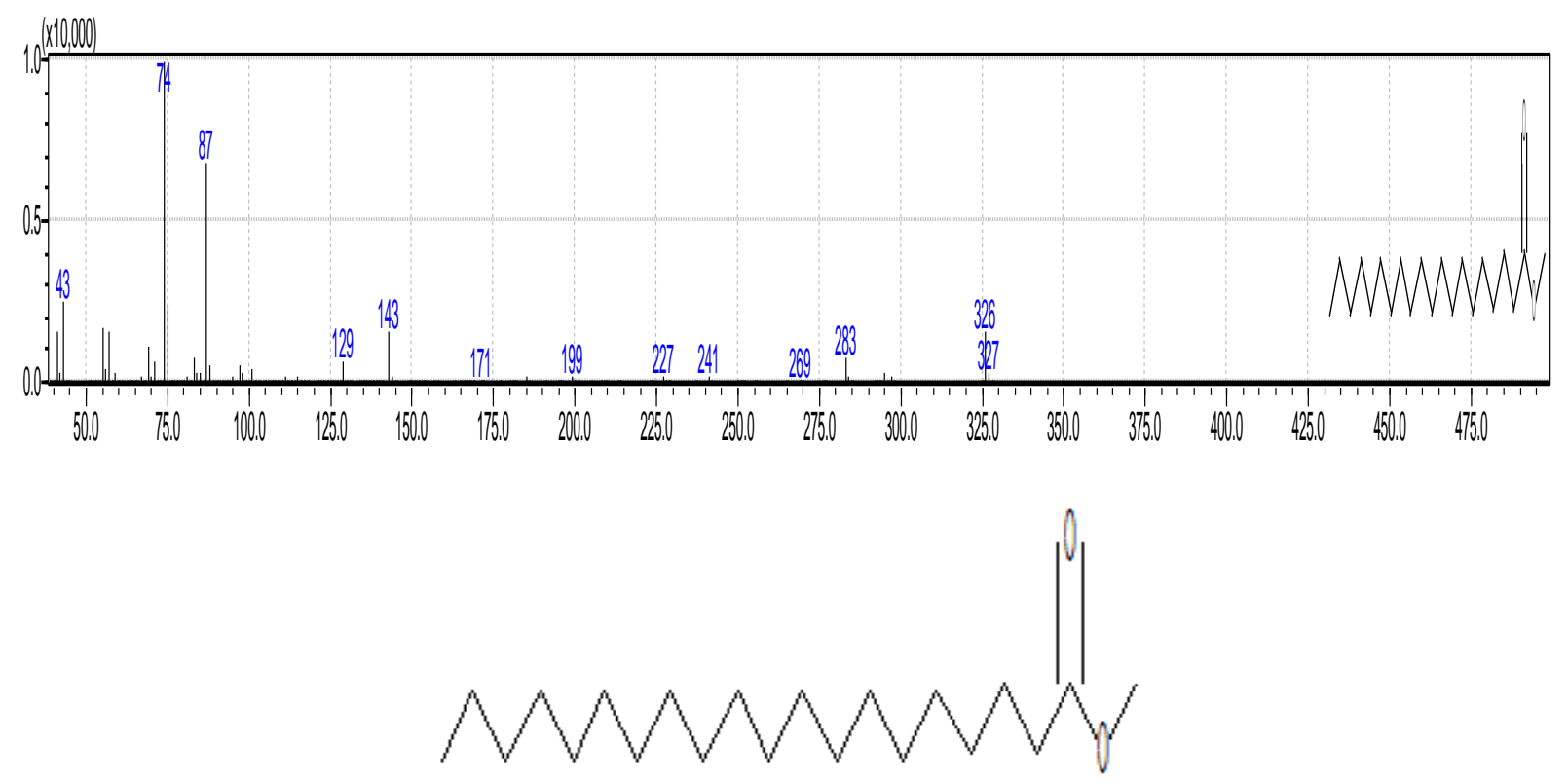

17/ 13-Docosenoic acid, methyl ester, (Z)-

Molecular weight 340. Formula C22H44O2 (Figure.17)
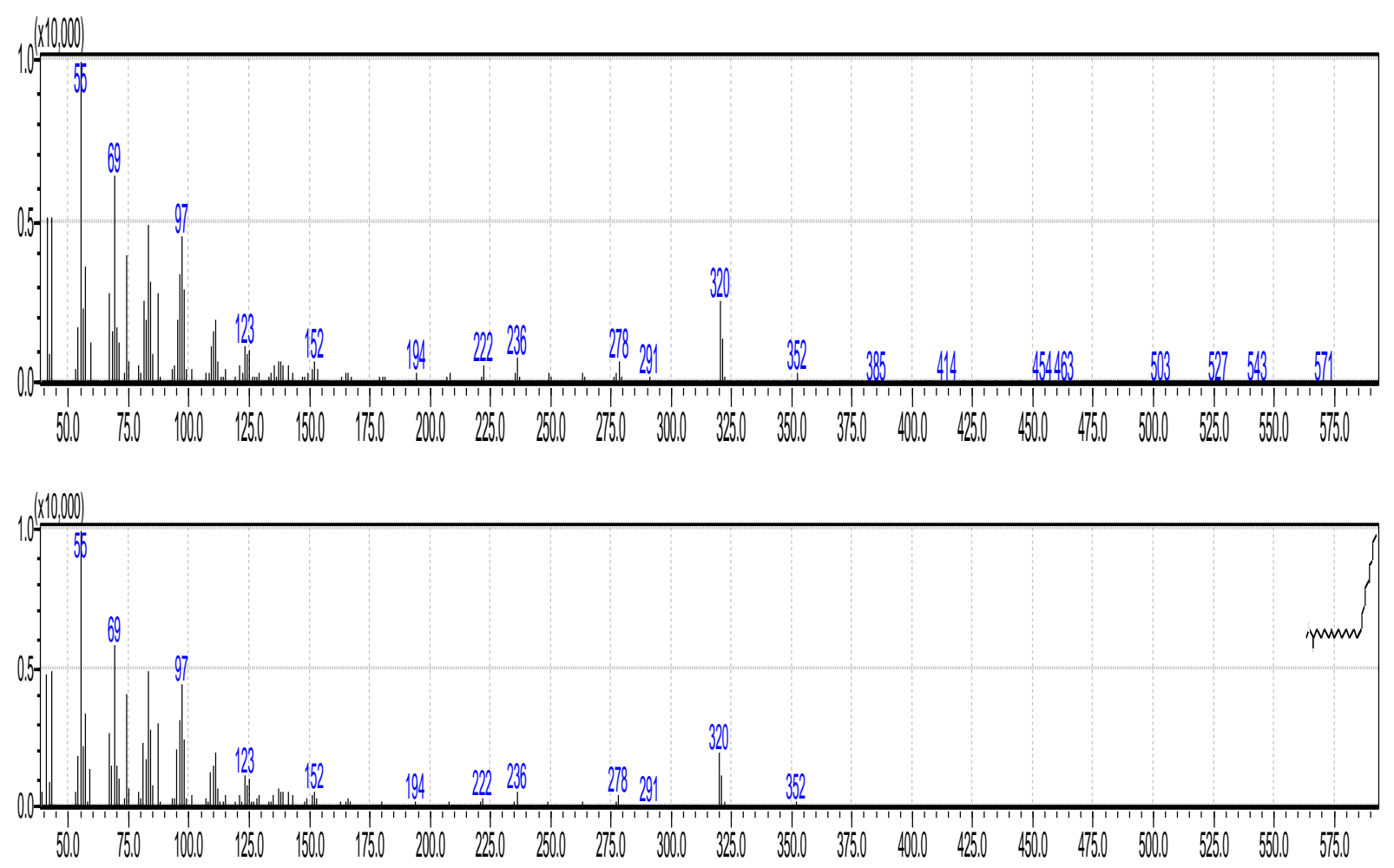
20 | International Journal of Scientific and Management Research 4(5) 1-29

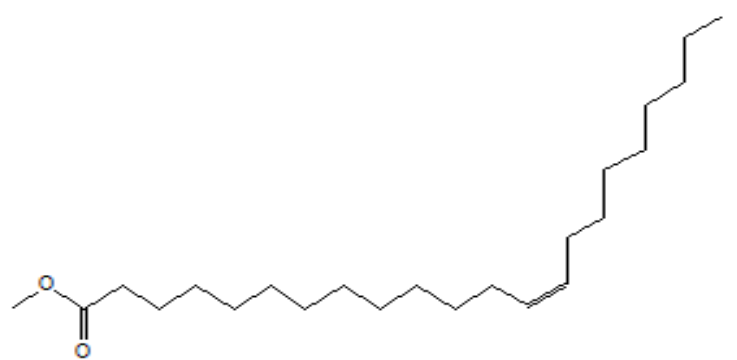

18/ Docosanoic acid, methyl ester \$\$ Behenic acid, methyl ester

Molecular weight 326. Formula C21H42O2 (Figure.18)
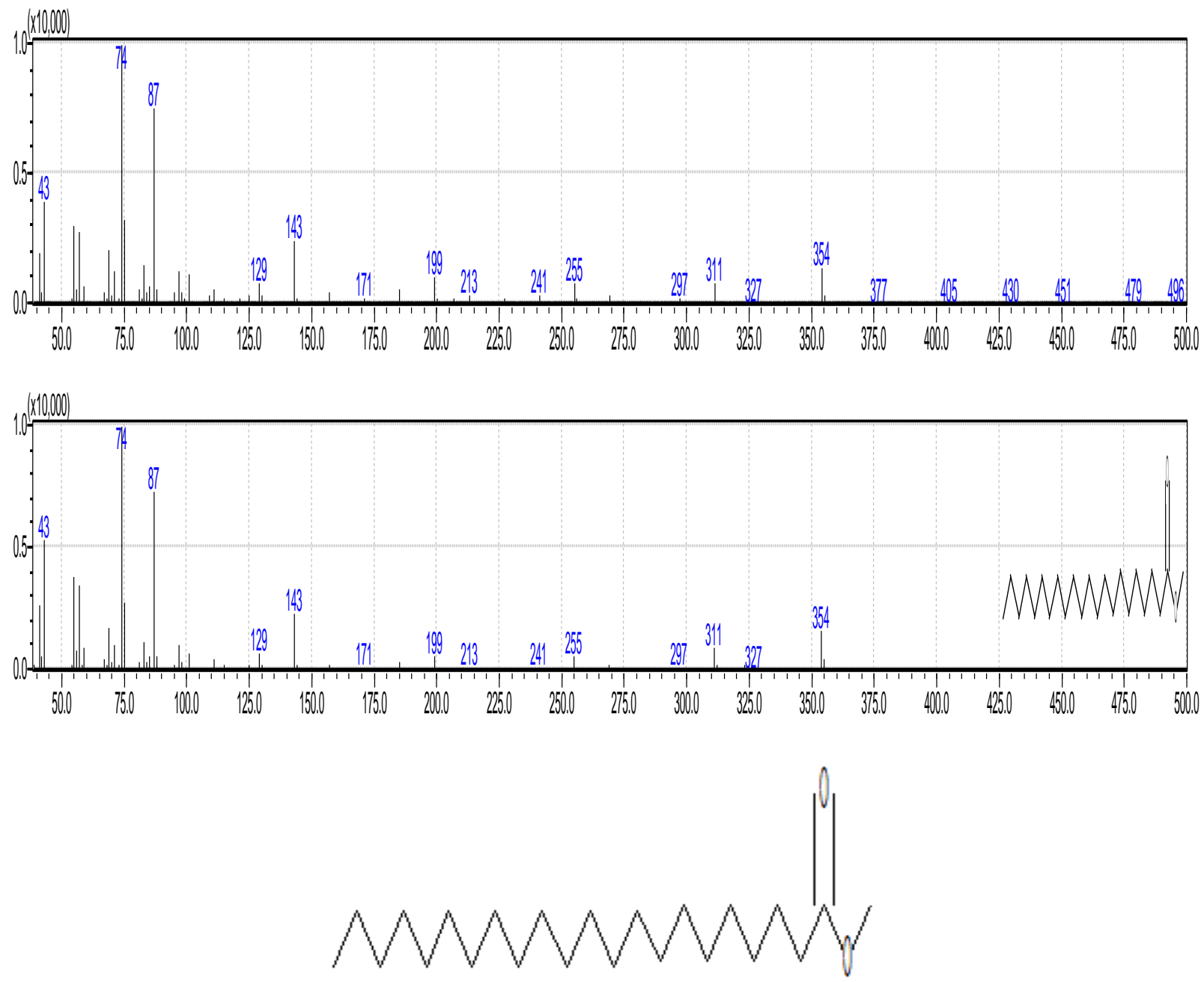

19/ Octadecanoic acid, 6-hydroxy-, methyl ester

Molecular weight 314. Formula C19H38O3 (Figure.19) 
21 | International Journal of Scientific and Management Research 4(5) 1-29
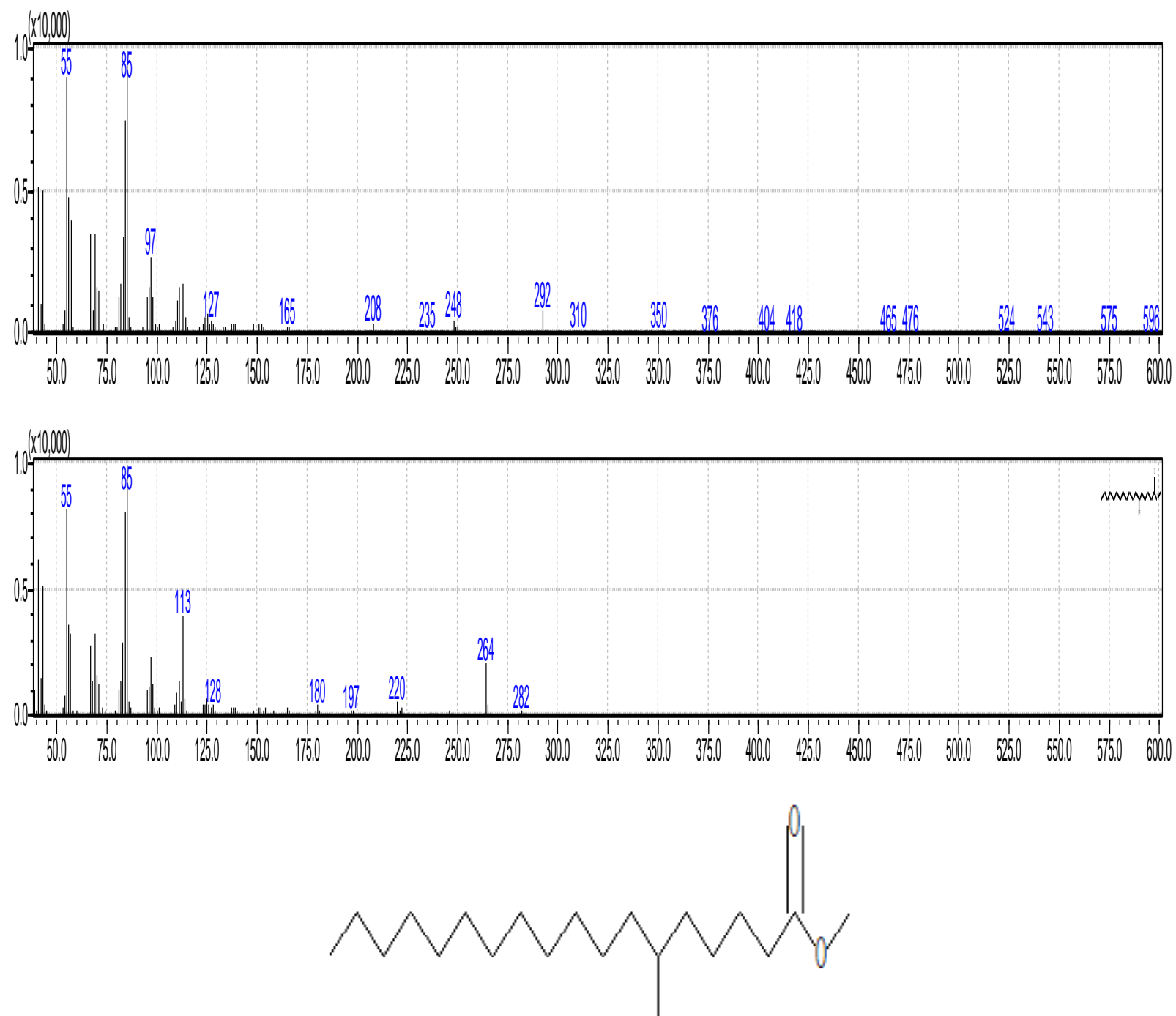

$\mathrm{OH}$

20/ 15-Tetracosenoic acid, methyl ester, $(Z)$ -

Molecular weight 368. Formula C24H48O2 (Figure.20)

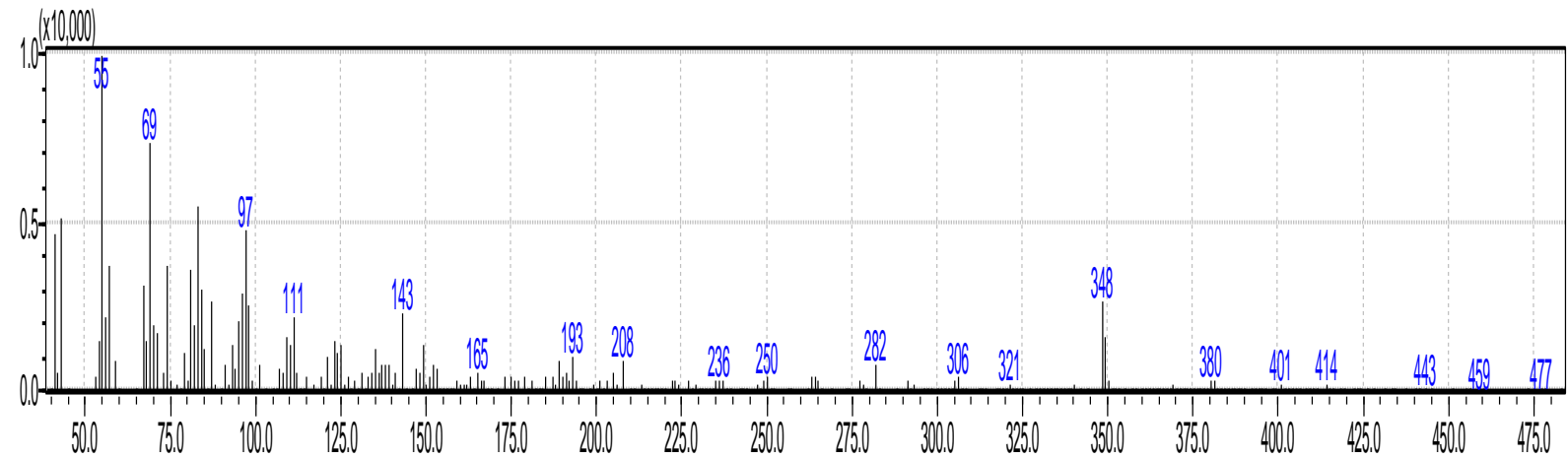




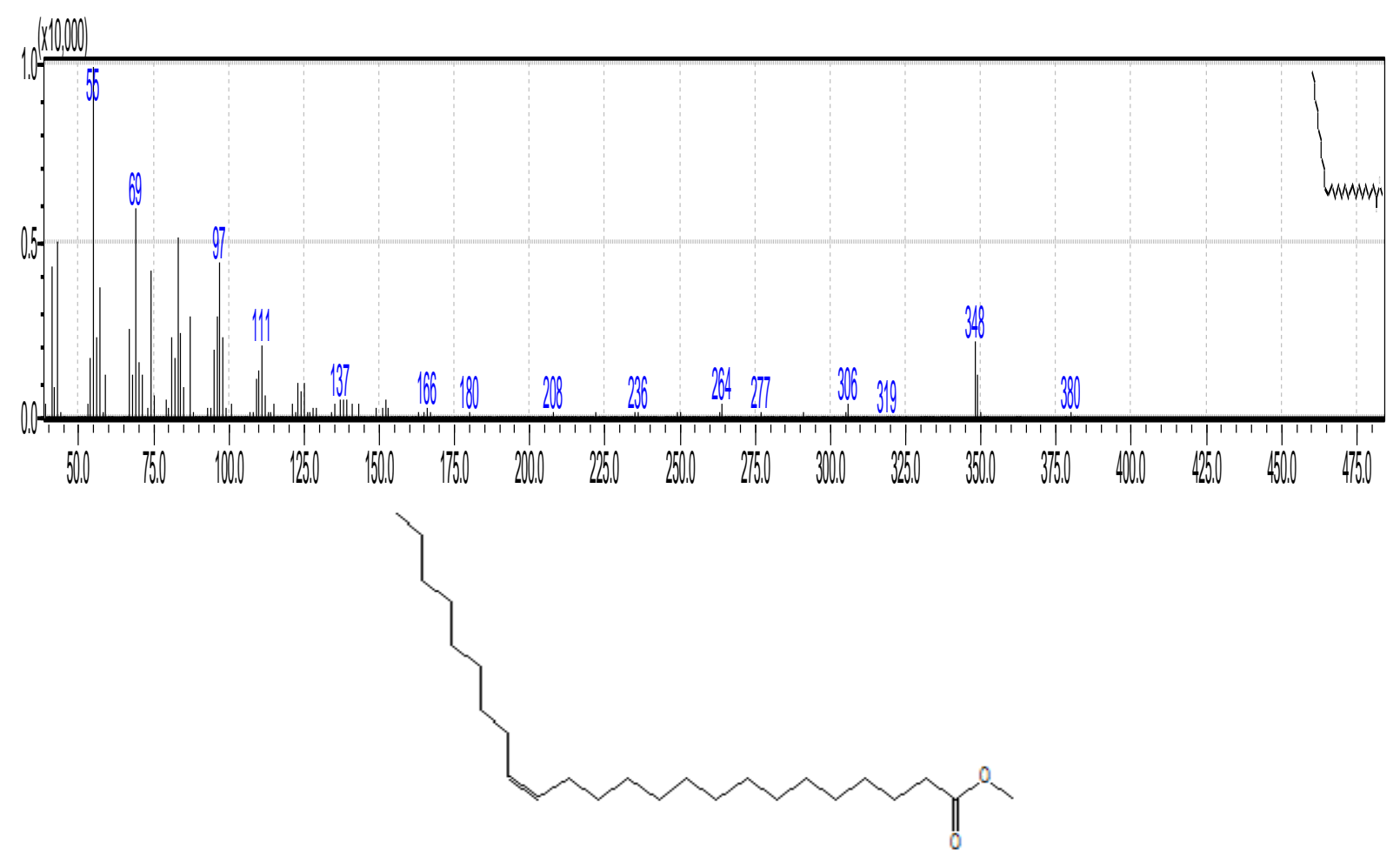

\section{1/ Methyl 8-oxohexadecanoate}

Molecular weight 284. Formula C17H32O3 (Figure21)
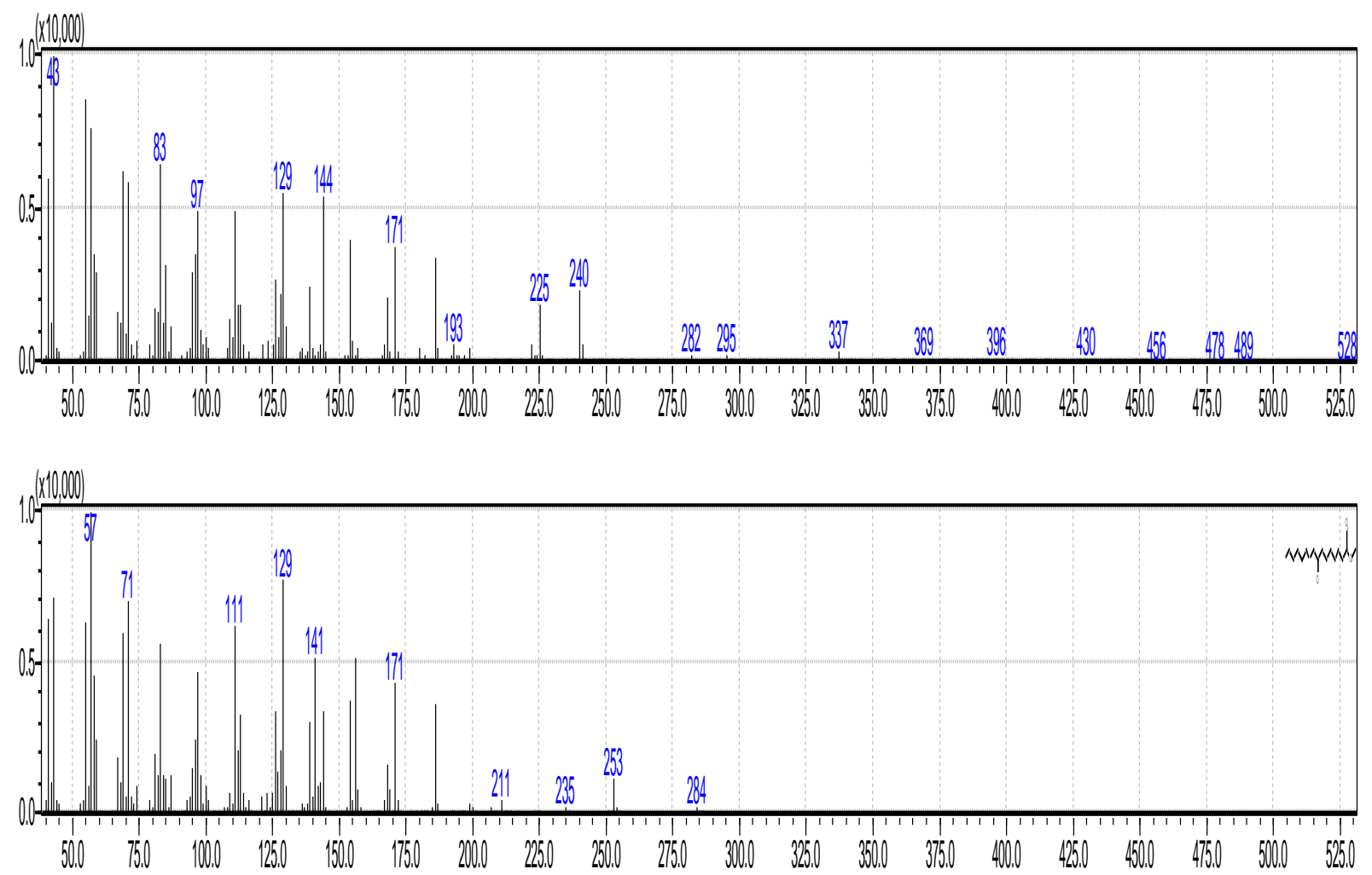


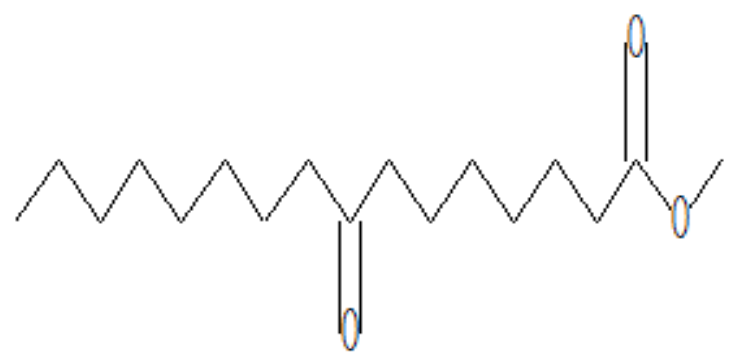

\section{2/ Tetracosanoic acid, methyl ester}

Molecular weight 382. Formula C25H50O2 (Figure.22)
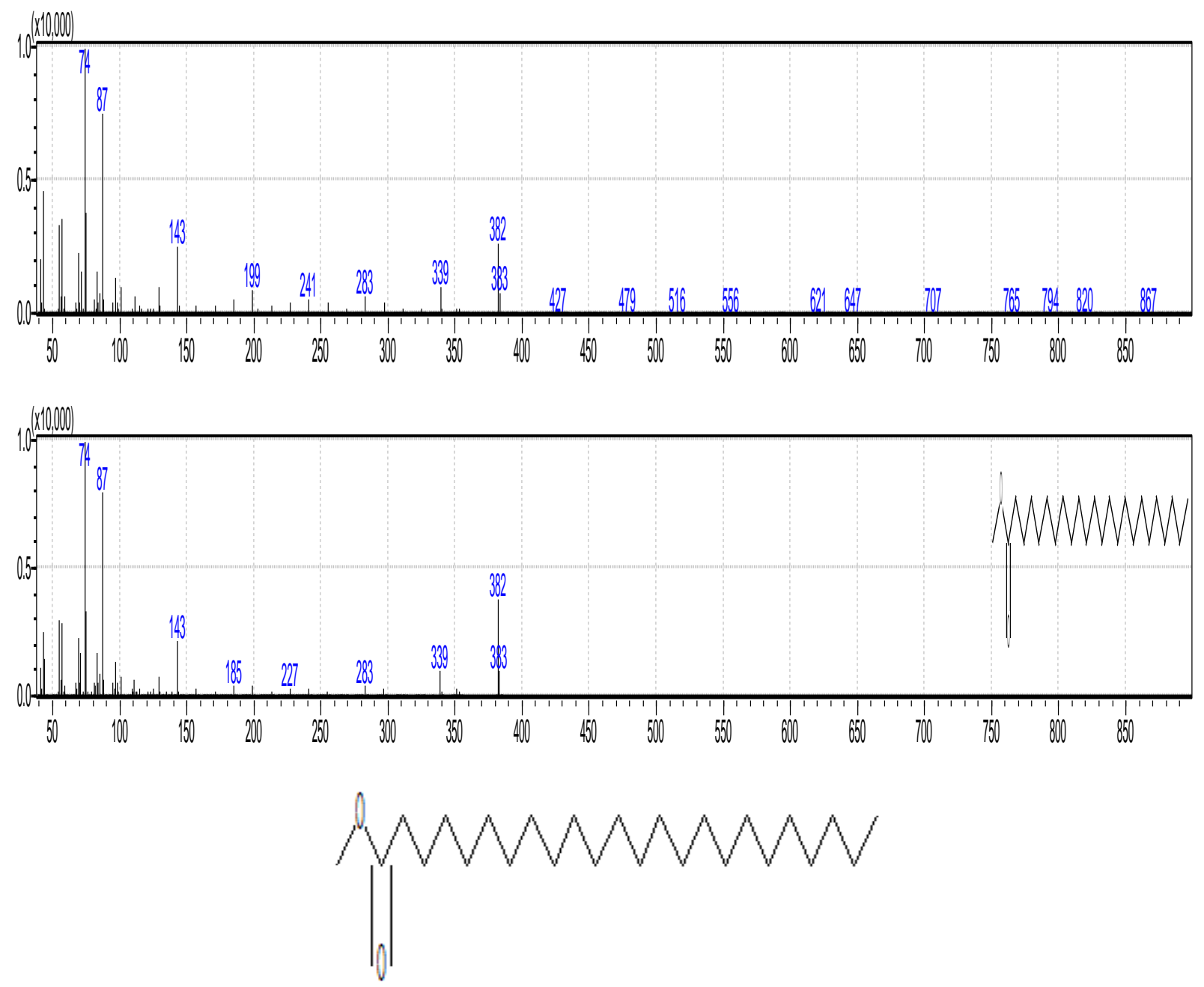

\section{3/ Erucic acid}

Molecular weight 338. Formula C22H42O2 (Figure.23) 

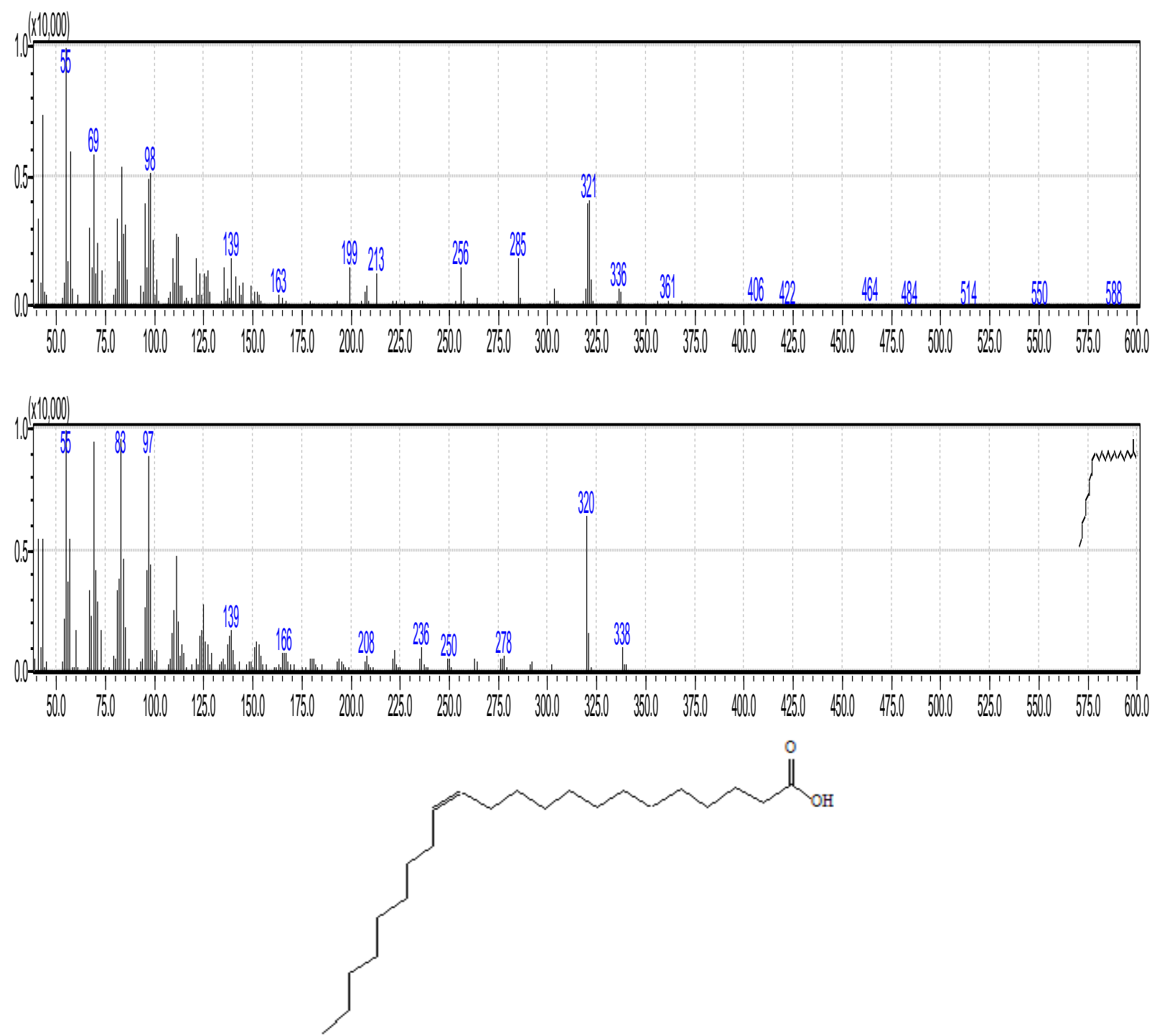

\section{4/ Hexacosanoic acid, methyl ester}

Molecular weight 410. Formula C27H54O2 (Figure.24)

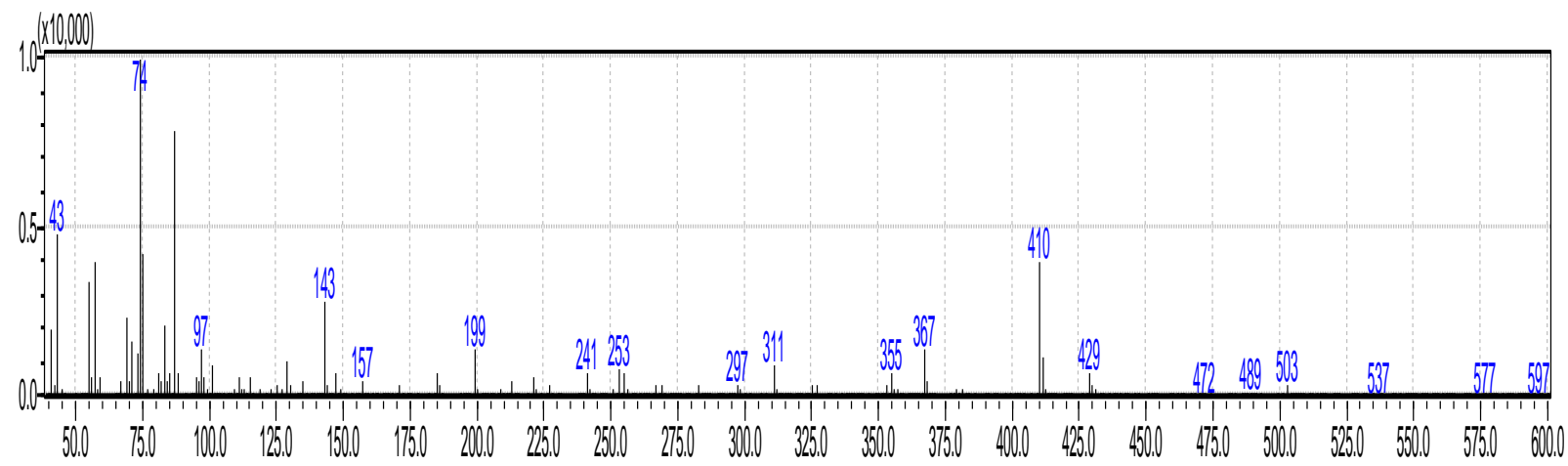


25 | International Journal of Scientific and Management Research 4(5) 1-29
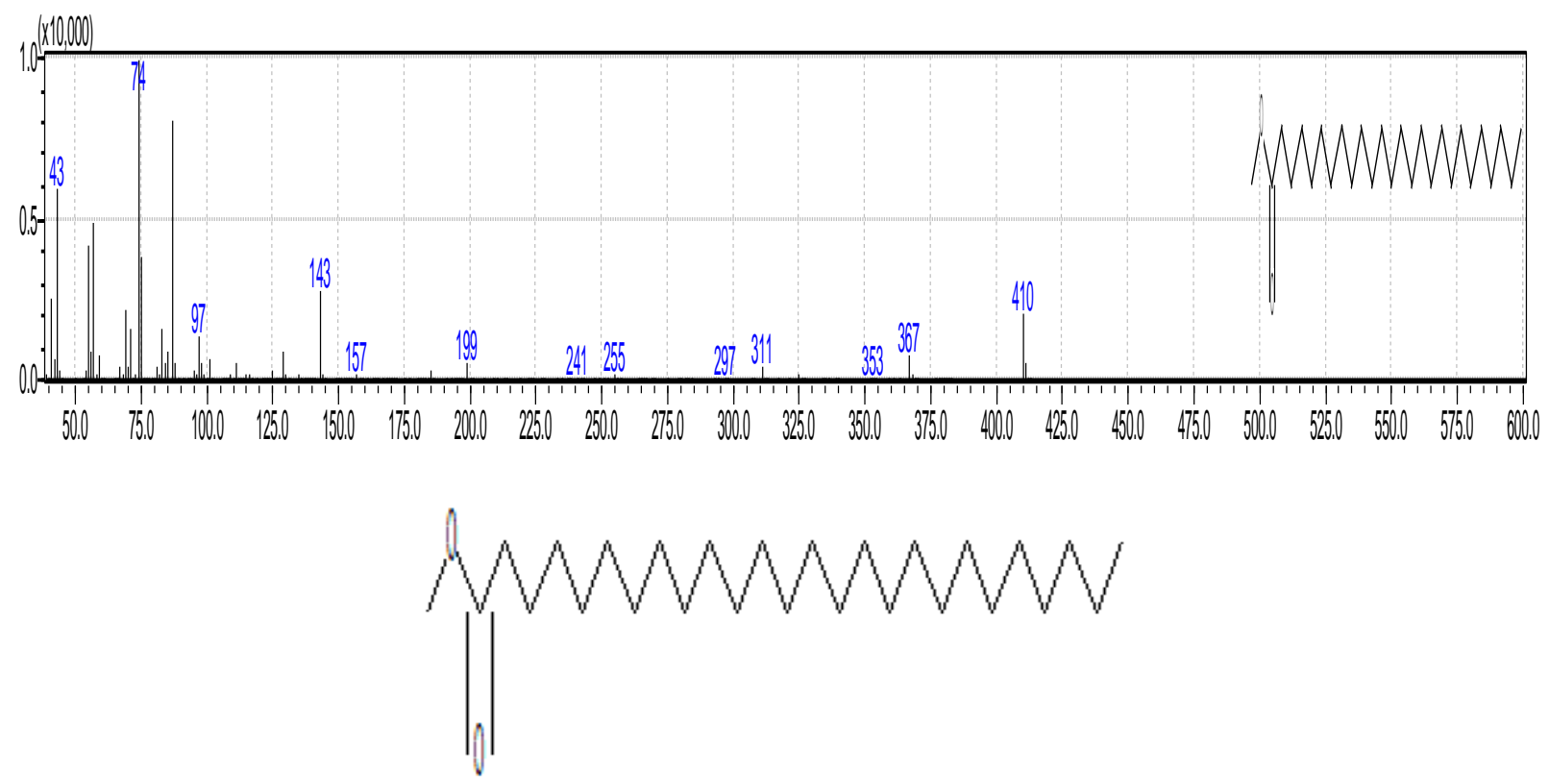

\section{5/ Stigmast-5-en-3-ol, Oleate}

Molecular weight 678. Formula C47H82O2 (Figure.25)
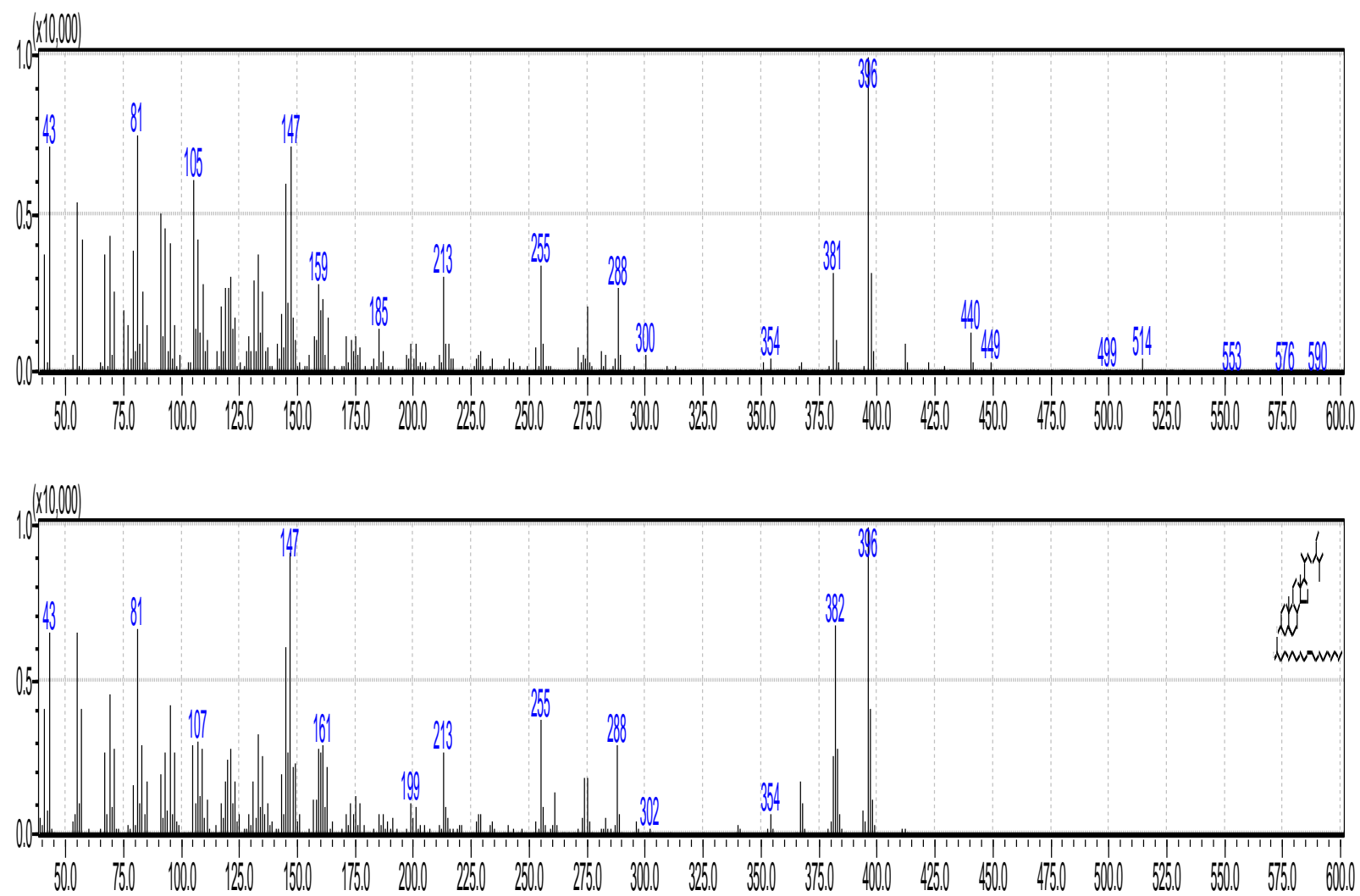
26 | International Journal of Scientific and Management Research 4(5) 1-29

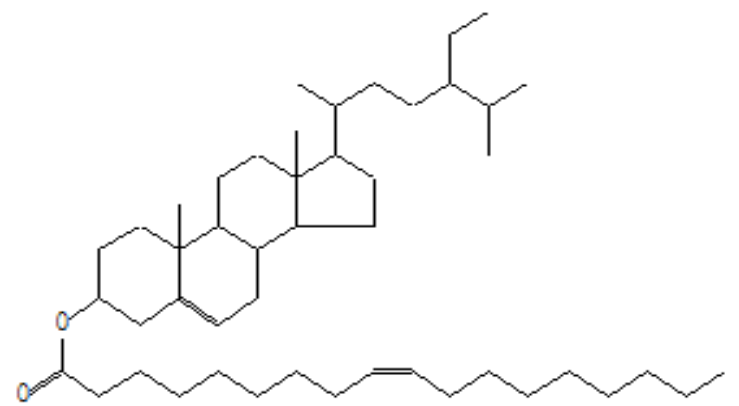

26/ 9, 19-Cycloergost-24(28)-en-3-ol, 4, 14-dimethyl-, acetate, (3.beta. 4. alpha., 5.alpha.)-

Molecular weight 468. Formula C32H52O2 (Figure.26)
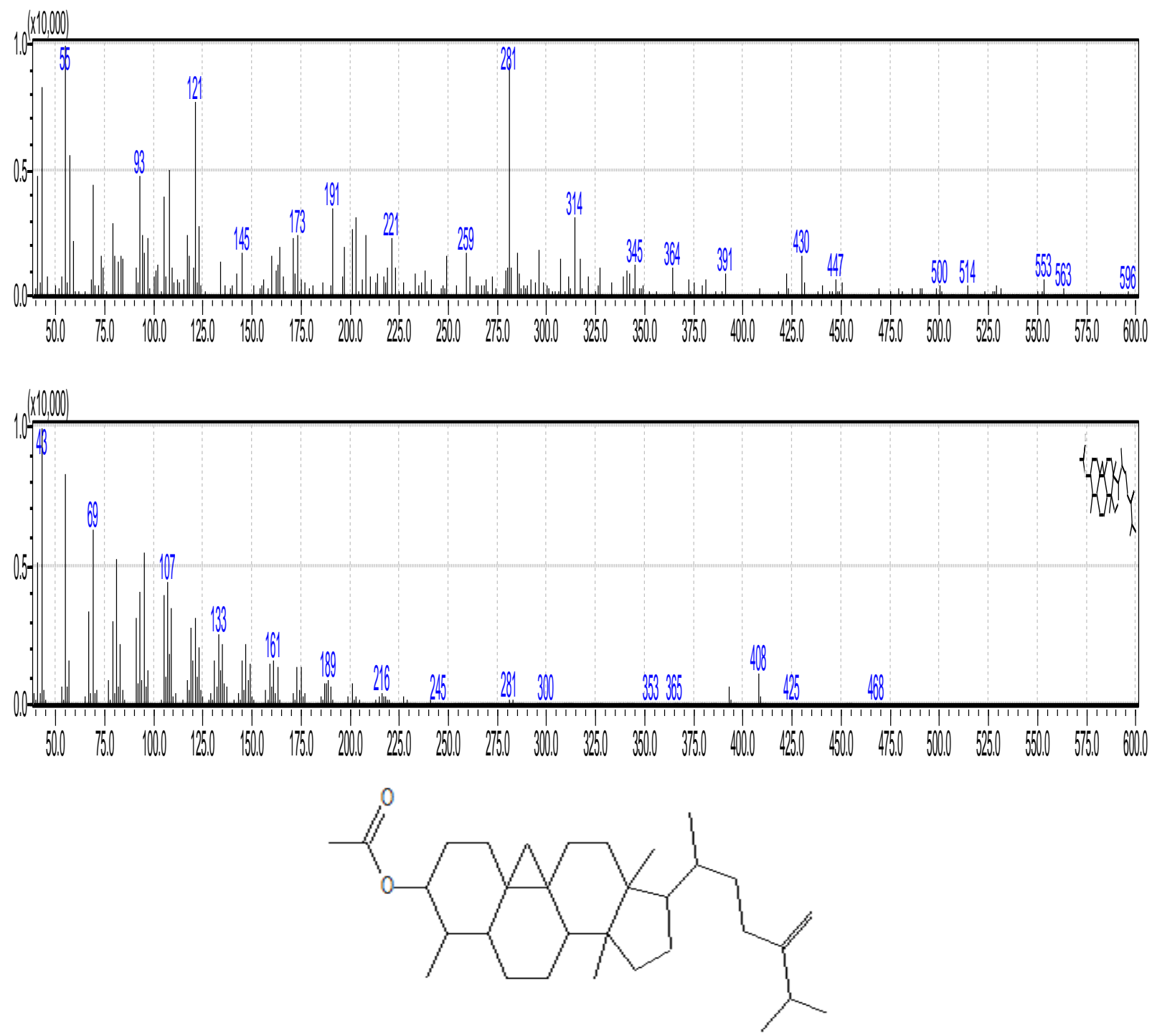


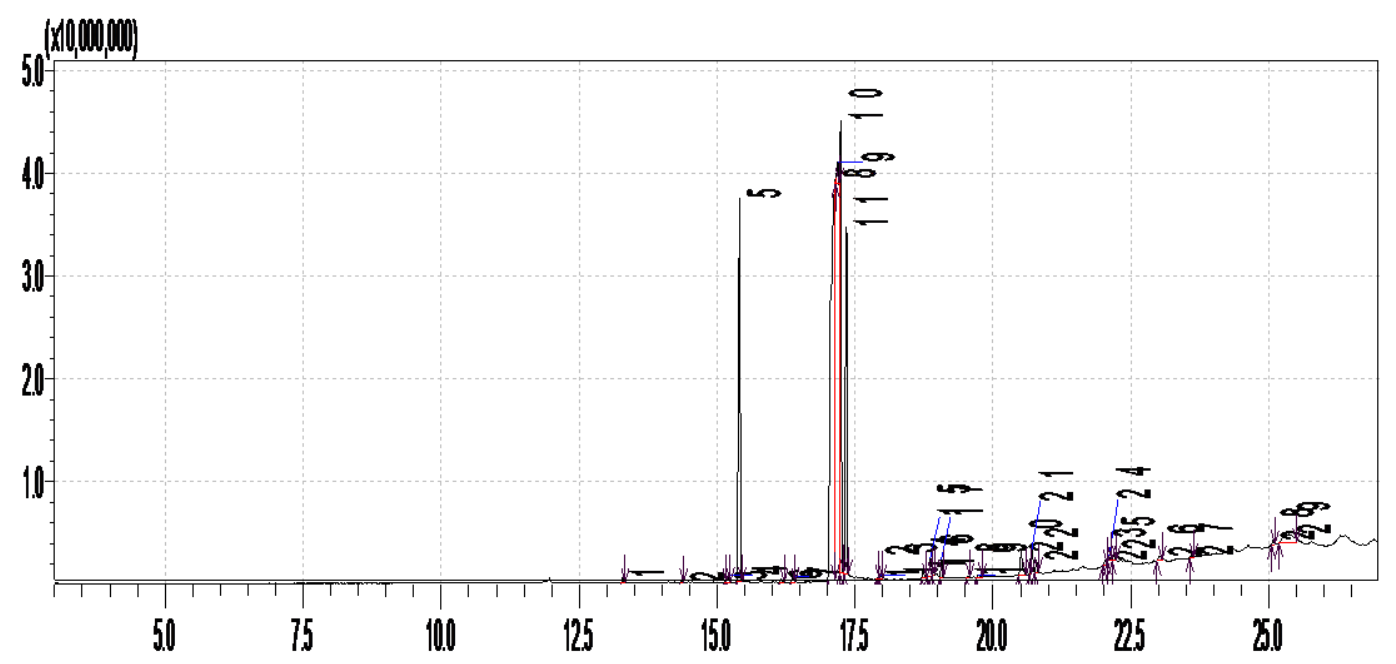

Figure.27.

\section{References}

1) Rubilar M, Gutiérrez C, Verdugo M, Shene C, Sineiro J. Flaxseed as a source of functional ingredients. J. Soil. Sci. Plant Nutr. 2010; 10(3):373-7.

2) D., Attar-Bashi, N., \& Sinclair, A. J. a-Linolenic acid and heart disease. In L. U. Thompson \& S. C. Cunnane (Eds.), Flaxseed in human nutrition (2003) (2nd ed., pp. 245-259). Champaign, IL: AOCS Press.

3) Bougnoux, P., \& Chajes, V. a-Linolenic acid and cancer. In L. U. Thompson \& S. C. Cunnane (Eds.), Flaxseed in human nutrition (2003). (2nd ed., pp. 232-244). Champaign, IL: AOCS Press.

4) Salini T.S, Divakaran D., Shabanamol S., Sharrel R., Jisha M.S.,World J. Pharm. Res. 3 (2014) 879.

5) Ajayi G.O., Olagunju J.A., Ademuyiwa O.C., Martins O. J Med Plant Res 5 (2011) 1756.

6) Sujana N., Ramanathan S., Vimala V., Sundaram M. Inter. J. Pharm. Pharmaceutical Sci. 4 (2012) 17.

7) Panigrahi S., Sundaram Muthuraman M., Natesan R., Pemiah B. Inter. J. Pharm. Pharmaceutical Sci. 6 (2014) 93.

8) Alaa A. Gaafar1, Zeinab A. Salama1*, Mohsen S. Askar2, Dardiri M. El-Hariri3, Bakry A. Bakry3. In Vitro antioxidant and antimicrobial activities of Lignan flax seed extract (Linumusitatissimum, L.). International Journal of Pharmaceutical Sciences Review and Research. Nov - Dec 2013; n 47, 291-297

9) Kajla P, Sharma A, Sood DR. Flaxseed a potential functional food source. J. Food Sci. technol. 2015; 52(4):1857-71. Available: https://doi.org/10.1007/s13197- 014-1293-y.

10) H. Tohma, E. Köksal, Ö. Kılıç, Y. Alan, M.A. Yılmaz, İ. Gülçin, E. Bursal and S.H. Alwasel (2016). RPHPLC/MS/MS analysis of the phenolic compounds, antioxidant and antimicrobial activities of Salvia L. species, Antioxidants, 5, 38.

11) İ. Gülçin (2012). Antioxidant activity of food constituents-An overview, Archiv. Toxicol. 86, 345-396. 
12) M. Topal, H. Gocer, F. Topal, P. Kalin, P. Polat Köse, İ. Gülçin, K. Cetin Çakmak, M. Küçük, L. Durmaz, A.C. Gören and S.H. Alwasel (2016). Antioxidant, antiradical and anticholinergic properties of cynarin purified from the Illyrian thistle (Onopordum Illyricum L.), J. Enzyme Inhib. Med. Chem. 31, 266-275. Material and Methods.

13) AOAC. Determination of crude oil. Official methods of analysis. 17th ed. Washington: Association of Official Analytical Chemists; 2000.

14) Erwa IY, Ali AM, Khalid EA, Omer AB, Ishag OA. Proximate composition, mineral elements content and physicochemical characteristics of Adansonia digitata L seed Oil. Int J Pharma Bio Sci. 2019; 10(4):119-26.

15) ISO I. 660: 2009(E) Animal and Vegetable Fats and Oils-Determination of acid value and acidity. ISO: Geneva, Switzerland; 2009.

16) Pegg, R. (2005). Measurement of primary lipid oxidation products. In R. E. Wrolstad, T. E. Acree, \& E. A. Decker (Eds.), Handbook of food analytical chemistry (pp. 515-564). New Jersey, NJ: Wiley.

17) Pearson, D. 1970. The chemical analysis of food. (6 ed). J.A. Churchill, London.

18) Wail, S.: Sue, T.T. and Yew Ai, J.1995. Palm Oil Research Institute of Malaysia. Ministry of primary Industries. Malaysia. Published by palm Oil Research Institute of Malaysia.

19) AOAC. Determination of Crude Oil. Official Methods of Analysis 17th Edition, Association of Official Agric Chem. Washington; 2000.

20) Cocks, L.U.and Van Rede. 1966. Laboratory Handbook for oil and fat analysis. Academic press. Inc. Ltd. London, New York.

21) Herchi W, Al Hujaili AD, Sakouhi F, Sebei K, Trabelsi H, Kallel H, Boukhchina S. Flaxseed hull: chemical composition and antioxidant activity during development. J Oleo Sci. 2014; ess14006.

22) Rabie Y. Khattab*, Mohammad A. Zeitoun, Quality evaluation of flaxseed oil obtained by different extraction techniques, LWT - Food Science and Technology,53,(2013) 338345.

23) Omer Adam Omer Ishag1*, Ayat A. Khalid1, Amina Abdi1, Ibrahim Yaagoub Erwa1, Awadalla Babiker Omer1 and Azhari H. Nour1, Proximate Composition, Physicochemical Properties and Antioxidant Activity of Flaxseed, Annual Research \& Review in Biology 34(2): 1-10, 2019.

24) X.G. Zou, X.L. Chen, J.N. Hu, Y.F. Wang, D.M. Gong, X.M. Zhu and Z.Y. Deng (2017). Comparisons of proximate compositions, fatty acids profile and micronutrients between fiber and oil flaxseeds (Linum usitatissimum L.). J. Food Comp. Anal. 62, 168-176.

25) Nemes SM, Orsat V, Evaluation of a microwave-assisted extraction method for lignan quantification in flaxseed cultivars and selected oil seeds. Food Anal Method, 5, 2011, 551-563.

26) Asli Can Karaca, Michael Nickerson, Nicholas H. Low, Microcapsule production employing chickpea or lentil protein isolates and maltodextrin: Physicochemical properties and oxidative protection of encapsulated flaxseed oil, Food Chemistry, 139, (2013) 448-457.

27) Kasote, D.M, Flaxseed phenolic as natural antioxidants, International Food Research Journal 20(1): 27-34 (2013). 
28) Hatica Han, Hasibe Yılmaz and İlhami Gülçin, Antioxidant Activity of Flaxseed (Linum usitatissimum L.) shell and Analysis of Its Polyphenol Contents by LC-MS/MS, Rec. Nat. Prod. 12:4 (2018) 397-402.

29) Hyeon-Jeong Son and Kyung Bin Son, Antimicrobial Activity of Flaxseed Meal Extract against Escherichia coli O157:H7 and Staphylococcus aureus Inoculated on Red Mustard, J. Microbiol. Biotechnol. (2017), 27(1), 67-71.

30) H. Özbek, Z. Güvenalp, T. Özek, H.G. Sevindik, H. Yuca, K.Ö. Yerdelen and L.Ö. Demirezer (2017). Chemical composition, antioxidant and anticholinesterase activities of the essential oil of Origanum rotundifolium Boiss. From Turkey, Rec. Nat. Prod. 11(5), 485-490.

\section{Works Cited}

Rasha Khalid Abbas. (2021). Physicochemical Properties and Determination of Some Bioactive Phytochemical Constituents From Linum Usitatissimum L Oil (Flaxseed) by Gas Chromatographymass Spectrometry (GC-MS) and Atomic Absorption. International Journal of Scientific and Management Research, 04(05), 1-29. doi:http://doi.org/10.37502/IJSMR.2021.4501 